\title{
A Regional, Early Spring Bloom of Phaeocystis pouchetii on the New England Continental Shelf
}

\author{
Walker O. Smith \\ Virginia Institute of Marine Science
}

Weifeng G. Zhang

Andrew Hirzel

et al

Follow this and additional works at: https://scholarworks.wm.edu/vimsarticles

Part of the Oceanography Commons

\section{Recommended Citation}

Smith, Walker O.; Zhang, Weifeng G.; Hirzel, Andrew; and et al, A Regional, Early Spring Bloom of Phaeocystis pouchetii on the New England Continental Shelf (2021). JGR Oceans, 126(2). doi: 10.1029/2020JC016856

This Article is brought to you for free and open access by the Virginia Institute of Marine Science at W\&M ScholarWorks. It has been accepted for inclusion in VIMS Articles by an authorized administrator of W\&M ScholarWorks. For more information, please contact scholarworks@wm.edu. 


\section{JGR Oceans}

\section{RESEARCH ARTICLE \\ 10.1029/2020JC016856 \\ Key Points: \\ - A large bloom of the haptophyte Phaeocystis pouchetii was observed off the coast of New England during early spring, 2018 \\ - The bloom was centered on Nantucket Shoals, but relaxation of physical constraints allowed it to propagate over larger areas \\ - Blooms like the one we assessed likely occur sporadically over the continental shelf and potentially disrupt regional food webs}

Supporting Information:

- Supporting Information S1

Correspondence to:

W. O. Smith Jr.,

wos@vims.edu

\section{Citation:}

Smith Jr., W. O., Zhang, W. G., Hirzel, A., Stanley, R. M., Meyer, M. G., Sosik, H., et al. (2021). A regional, early spring bloom of Phaeocystis pouchetii on the New England continental shelf. Journal of Geophysical Research: Oceans, 126, e2020JC016856. https://doi. org/10.1029/2020JC016856

Received 8 OCT 2020 Accepted 29 DEC 2020

\section{A Regional, Early Spring Bloom of Phaeocystis pouchetii on the New England Continental Shelf}

\author{
Walker O. Smith Jr. ${ }^{1,2}$ (D, Weifeng G. Zhang ${ }^{3}$ (D), Andrew Hirzel ${ }^{3}$, Rachel M. Stanley ${ }^{4}$, \\ Meredith G. Meyer ${ }^{1}$, Heidi Sosik ${ }^{3}$ (D), Philip Alatalo ${ }^{3}$ (D) , Hilde Oliver $^{3}$ (D), Zoe Sandwith ${ }^{3}$, \\ E. Taylor Crockford ${ }^{3}$, Emily E. Peacock ${ }^{3}$, Arshia Mehta ${ }^{4}$, and Dennis J. McGillicuddy Jr. ${ }^{3}$ (i) \\ ${ }^{1}$ Virginia Institute of Marine Science, William \& Mary, Gloucester Pt., VA, USA, ${ }^{2}$ School of Oceanography, Shanghai \\ Jiao Tong University, Shanghai, China, ${ }^{3}$ Woods Hole Oceanographic Institution, Woods Hole, MA, USA, ${ }^{4}$ Department \\ of Chemistry, Wellesley College, Wellesley, MA, USA
}

\begin{abstract}
The genus Phaeocystis is distributed globally and has considerable ecological, biogeochemical, and societal impacts. Understanding its distribution, growth and ecological impacts has been limited by lack of extensive observations on appropriate scales. In 2018, we investigated the biological dynamics of the New England continental shelf and encountered a substantial bloom of Phaeocystis pouchetii. Based on satellite imagery during January through April, the bloom extended over broad expanses of the shelf; furthermore, our observations demonstrated that it reached high biomass levels, with maximum chlorophyll concentrations exceeding $16 \mu \mathrm{g} \mathrm{L} \mathrm{L}^{-1}$ and particulate organic carbon levels $>95 \mu \mathrm{mol} \mathrm{L}{ }^{-1}$. Initially, the bloom was largely confined to waters with temperatures $<6^{\circ} \mathrm{C}$, which in turn were mostly restricted to shallow areas near the coast. As the bloom progressed, it appeared to sink into the bottom boundary layer; however, enough light and nutrients were available for growth. The bloom was highly productive (net community production integrated through the mixed layer from stations within the bloom averaged $1.16 \mathrm{~g} \mathrm{C} \mathrm{m}^{-2} \mathrm{~d}^{-1}$ ) and reduced nutrient concentrations considerably. Long-term coastal observations suggest that Phaeocystis blooms occur sporadically in spring on Nantucket Shoals and presumably expand onto the continental shelf. Based on the distribution of Phaeocystis during our study, we suggest that it can have a significant impact on the overall productivity and ecology of the New England shelf during the winter/spring transition.
\end{abstract}

Plain Language Summary The coastal ocean off New England supports substantial fish harvests and large numbers of marine mammals and birds. These are in turn supported by the growth of phytoplankton, photosynthetic microorganisms that are the base of the marine food web. A large accumulation of a particular type of phytoplankton, Phaeocystis, was observed both during a research cruise to the region and from earth-orbiting satellites. Phaeocystis is unusual, in that it forms gelatinous colonies that are millimeters in diameter. The colonies are considered to be unpalatable to many organisms that feed on phytoplankton, and accumulations of this genus may be harmful to the regional food web. Waters with elevated abundance of Phaeocystis were largely confined to the Nantucket Shoals area, likely by physical processes, but occasionally high concentrations of Phaeocystis extended over broader areas and sank to depth. After the bloom disappeared from surface waters, it was sustained in the bottom boundary layer landward of the $60-\mathrm{m}$ isobath where light was sufficient to support growth. Understanding the physical-biological interactions in the coastal system provides a basis for predicting these blooms of potentially harmful algae, and may lead to a better prediction of their impacts on coastal systems.

\section{Introduction}

The genus Phaeocystis is distributed globally throughout the world's oceans, forming blooms in European, Asian, Antarctic, Arctic, and North American waters and in tropical, polar and temperate systems. It often (but not always) releases dimethylsulfide into the surface layer, which has the potential for altering weather and climate patterns (Charlson et al., 1987; Stefels et al., 1995), and significantly influences the biogeochemistry of sulfur (Wang et al., 2016). In addition, Phaeocystis is considered to be largely "unpalatable" to zooplankton grazers (Nejstgaard et al., 2007). The ecology and physiology of Phaeocystis are relatively well studied, but given the variety of environments the genus can occupy, it is difficult to generalize about
(C) 2021. American Geophysical Union. All Rights Reserved. 
its responses to oceanographic conditions or ecological impacts. Phaeocystis has an unusual life cycle that includes both solitary cells and colonies; the colonies can reach considerable size (up to $2 \mathrm{~mm}$ in most systems; Rousseau et al., 1994), but up to $3 \mathrm{~cm}$ in others (Smith et al., 2014). Colonies are generally spherical during active growth, with cells held by a mucopolysaccharide envelope (Hamm et al., 1999). During periods of physiological stress, the colonies have been shown to release flagellated, solitary cells and form "ghost colonies" (Smith et al., 2017; Verity et al., 1988b).

Massive blooms of the colonial stage have been reported in many systems, particularly those with elevated nutrient levels (e.g., North Sea, Barents Sea, Greenland Sea, Ross Sea, Arabian Gulf; Lancelot et al., 1998). Reports of Phaeocystis occurrence in North American waters are far less frequent. From a long time-series of discrete samples collected in Narragansett Bay, RI, Smayda (1998) suggested that the occurrence in 1977 of Phaeocystis pouchetii was a "novel appearance," meaning it was unprecedented in the area. Smayda also suggested that when Phaeocystis did occur it became established as a keystone species and had a disproportionate impact on the local ecology. Verity et al. (1988a, 1988b) established microcosms using natural seawater inoculations from Narragansett Bay and found that blooms were greatly enhanced by the addition of nutrients. A number of reports indicated that P. pouchetii occurred in the southern Gulf of Maine as well (Borkman et al., 2016; Jiang et al., 2014) and described the importance of elevated nutrients associated with terrestrial run-off in driving the success of this species and its appearance in the winter-spring transition. These limited reports suggest that Phaeocystis does occur in New England waters, but that it is only a modest contributor to biomass over an annual cycle.

On other continental shelves, Phaeocystis is a major contributor to primary productivity and carbon dynamics (Kaufman et al., 2017; Lancelot et al., 1998). New England continental shelves are known to be highly productive, based both on observations and satellite imagery (e.g., Marra et al., 1990; Ryan et al., 1999b), but the contribution of Phaeocystis to this production is poorly constrained. Water on the New England shelf originates mostly from the Gulf of Maine and the Scotian shelf (Chapman et al., 1986), and its motion and properties exhibit strong variation in both space and time (e.g., Lentz et al., 2003; Wilkin, 2006). The shelf water is separated from the offshore waters by a shelf break front that is susceptible to intermittent nonlinear instabilities and strong episodic interactions with Gulf Stream warm-core rings that impinge on the continental slope (Lozier et al., 2002; Zhang \& Gawarkiewicz, 2015a, 2015b). As a result, the New England shelf has significant along- and cross-shelf fluxes of nutrients that control the biological characteristics, both at the shelf break and inshore on the continental shelf (Falkowski et al., 1988; Ryan et al., 1999a; Zhang et al., 2013). Satellite and in situ observations have revealed strong temporal and spatial variation in phytoplankton biomass on the continental shelf (e.g., Xu et al., 2011). Despite these observations, our understanding of the processes that control the shelf ecosystem dynamics is still inadequate.

We studied the physical processes and the associated chemical and biological responses on the New England continental shelf and shelf break in a series of three cruises. The region is also being investigated through the Northeast US Shelf Long Term Ecological Research (NES-LTER) project, as well as being the site of the Ocean Observatories Initiative Pioneer Array (Gawarkiewicz \& Plueddemann, 2018). During our first cruise (April 16-29, 2018), we found a large bloom of the colonial haptophyte $P$. pouchetii and documented the bloom's vertical and horizontal extent, changes through time, and relationship to environmental characteristics. We conclude that the bloom was regional in character and was an unusual and unreported feature of the productivity cycle of inshore coastal waters, one that could have a substantial impact on both coastal and shelf ecology.

\section{Materials and Methods}

\subsection{Station Methodology}

The first Shelfbreak Productivity Interdisciplinary Research Operation at the Pioneer Array (SPIROPA) cruise was conducted on the $R / V$ Neil Armstrong from April 16-29, 2018 (AR29). Additional data were obtained from the NES-LTER cruise (AR28B) conducted from April 3-13, 2018. The program objectives were to understand the potential mechanisms that might stimulate phytoplankton growth near the shelf break. Our plan was to sample repeatedly a transect extending from the inner continental shelf off the slope, 


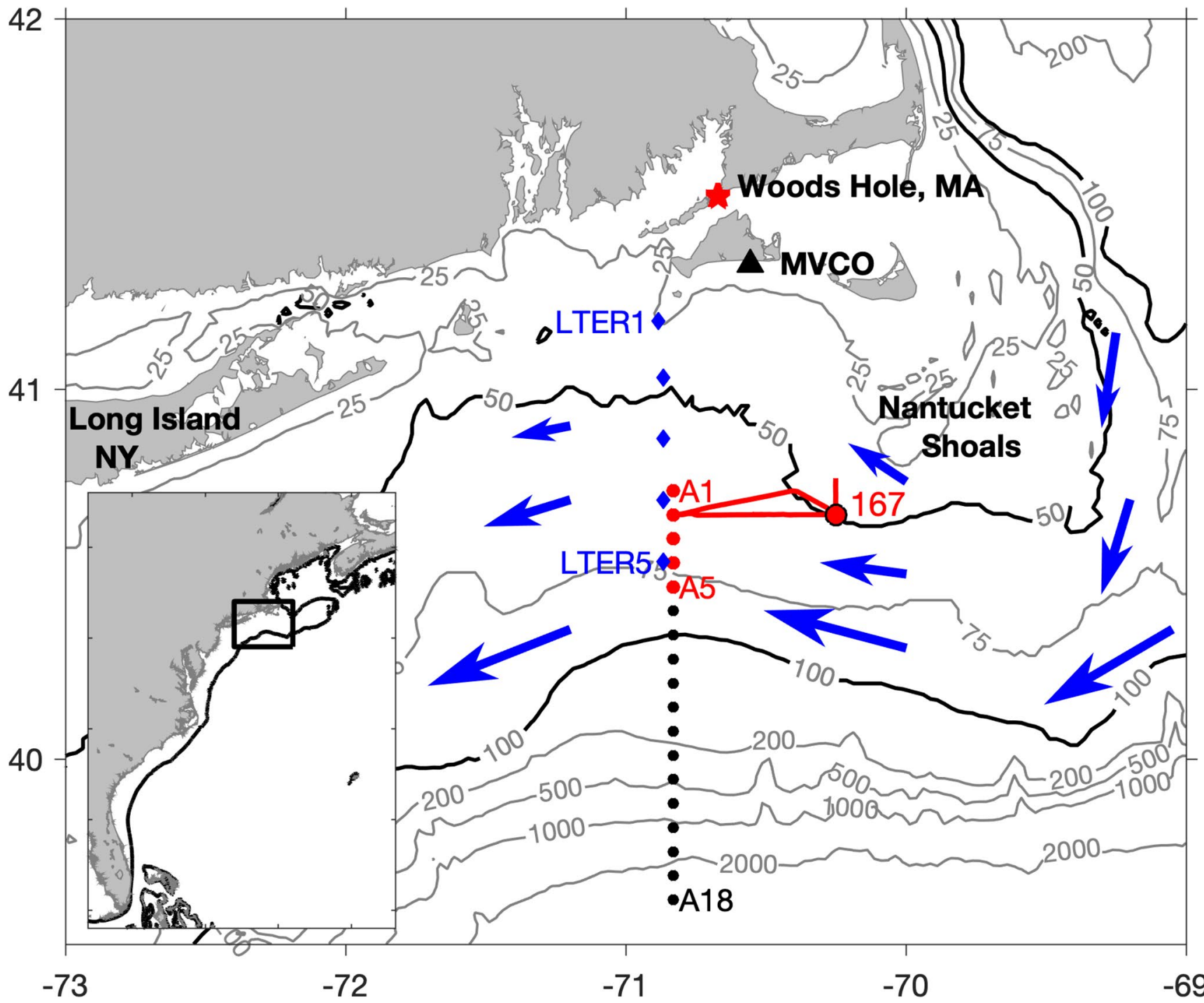

Figure 1. Map of the study area and station locations occupied during two cruises. Stations were reoccupied approximately every 2 days; distance between stations was ca. $5 \mathrm{~km}$. Stations indicated by the red dots were those intensively analyzed for Phaeocystis. The solid red lines indicate the track of an excursion to the east to sample a region with high abundances of Phaeocystis. Station 167 was sampled to assess the vertical distribution of Phaeocystis pouchetii. Blue triangles represent locations of stations sampled by the NES-LTER program and the black triangle indicates the Martha's Vineyard Coastal Observatory. Generalized pattern of currents also indicated by blue arrows (after Limeburner \& Beardsley, 1982).

with stations ca. $7 \mathrm{~km}$ apart, allowing for the characterization of mesoscale and submesoscale variability. A variety of measurements (continuous and discrete) were made, including phytoplankton abundance (Imaging Flow Cytobot and Video Plankton Recorder), productivity $\left({ }^{14} \mathrm{C}\right.$-uptake, which quantifies net primary productivity; triple oxygen isotopes, which quantify gross primary productivity; and $\mathrm{O}_{2} / \mathrm{Ar}$ ratios, which quantifies net community production), zooplankton abundance, microzooplankton grazing, and estimates of particulate matter concentrations. Sampling was conducted in conjunction with the Pioneer Array facilities (glider sampling, REMUS missions, moorings). Most stations were occupied on a 125-km north-south transect perpendicular to the shelf break at $70.8^{\circ} \mathrm{W}$ (Figure 1). At each station, water was collected using a CTD-rosette system with 24 10-L Niskin bottles, a photosynthetically active radiation (PAR) sensor (BioSpherical Instruments), fluorometer (WetLabs FLNTURTD), and beam transmissometer (WetLabs C- Star). Additional data were obtained from Cruise AR28B, which was a maintenance cruise for the Pioneer Array, as well as part of the NES-LTER project. Inshore stations were occupied on April 3-4 inshore of and at the locations sampled during AR29. 
Water was collected with the Niskin bottles at various depths between the surface to within $5 \mathrm{~m}$ or less of the bottom on the shelf. Discrete samples were taken for nutrients, chlorophyll, particulate organic carbon and nitrogen, oxygen/argon concentrations, and phytoplankton taxonomy. Nutrients (nitrate + nitrite, phosphate, ammonium, and silicic acid) were filtered through $0.4 \mu \mathrm{m}$ polycarbonate filters and frozen in acid-washed polyethylene bottles. All samples were run postcruise at the Woods Hole Oceanographic Institution Nutrient Analytical Facility. Duplicate chlorophyll samples (290 mL) were filtered through GF/F Whatman filters under low ( $0.5 \mathrm{~atm})$ vacuum and immediately frozen in liquid nitrogen for later laboratory analyses. Samples were thawed and extracted in $90 \%$ acetone and analyzed by standard fluorometric methods (JGOFS, 1996). Particulate organic carbon (POC) and nitrogen (PON) concentrations were determined by filtering known volumes (from 0.25 to $2.0 \mathrm{~L}$ ) of seawater under low vacuum through precombusted $\left(450^{\circ} \mathrm{C}\right.$ for $2 \mathrm{~h}$ ) Whatman GF/F filters (Gardner et al., 2000). All samples were stored in precombusted glass vials, dried at $60^{\circ} \mathrm{C}$, and analyzed on a Costech ECS Model 4010 elemental analyzer at the Virginia Institute of Marine Science. Blanks were filters that had $<5 \mathrm{~mL}$ filtered seawater passed through a filter to correct for dissolved organic carbon adsorption onto the filters.

Phaeocystis and other nano- and microplankton were enumerated and sized according to images collected with an Imaging Flow Cytobot (IFCB; McLane Research Laboratories, Inc.). The IFCB measures not only fluorescence and light scattering, but also captures a high resolution $(\sim 1 \mu \mathrm{m})$ image of each cell, chain, or colony in a flowing seawater sample (Sosik \& Olson, 2007). On both AR28B and AR29, an IFCB was configured to sample $5 \mathrm{~mL}$ automatically from the ship's flowing seawater system at $\sim 25$ min intervals throughout the cruise. On AR29, an additional IFCB was used to analyze discrete $5 \mathrm{~mL}$ samples from the CTD-rosette casts. Images were automatically analyzed and assigned to taxonomic groups following approaches developed for the IFCB time series at the Martha's Vineyard Coastal Observatory (MVCO: Sosik \& Olson, 2007; Sosik et al., 2016). Across the full time series, the typical detection limit for P. pouchetii abundance is $0.005 \mathrm{~mL}^{-1}$. Species identification of $P$. pouchetii was confirmed through microscopic and $18 \mathrm{~S}$ molecular analysis of 62 samples taken between 2013 and 2017.

\subsection{Video Plankton Recorder Methodology}

Plankton were imaged with a Digital Autonomous Video Plankton Recorder (DAVPR; SeaScan, Inc.) to estimate the concentration and vertical distribution of plankton taxa (Davis et al., 2005). Camera resolution was ca. $40 \mu \mathrm{m}$, but the smallest individual colonies that could be defined were ca. $150 \mu \mathrm{m}$ (or $\sim 25$ pixels). Nearly all colonies were ca. $500 \mu \mathrm{m}$. The DAVPR was mounted on the side of the rosette to minimize differences between CTD and DAVPR measurements. Video images were collected at a rate of $20 \mathrm{~Hz}$. Individual $1,392 \times 1,040$ pixel video frames $(\sim 3 \mathrm{~mL}$ volume imaged) were analyzed by object-identification software to identify "regions of interest" (ROIs), which were then saved with a time-stamp naming convention. ROIs were initially automatically identified using a dual classifier (Hu \& Davis, 2006), which was trained using 200 ROIs for each taxon. ROIs containing Phaeocystis colonies were separated between two classification

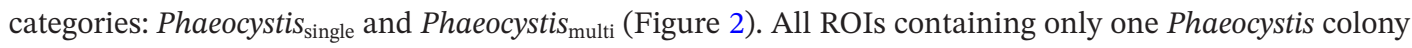

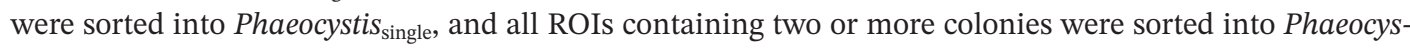
tis $s_{\text {multi }}$. Classified ROIs were then manually annotated to correct both false positives and false negatives for each Phaeocystis category. A subset of ROIs (200 ROIs from multiple casts) were manually counted to determine the mean number of Phaeocystis colonies per ROI within Phaeocystis multi $(2.5$ colonies per ROI). Total Phaeocystis abundance was estimated by multiplying the mean colony count by Phaeocystis multi $_{\text {distribution }}$ and adding Phaeocystis $_{\text {single }}\left(\right.$ i.e., Phaeocystis $s_{\text {total }}=$ Phaeocysti $_{\text {single }}+2.5 \times$ Phaeocystis $_{\text {multi }}$ ). Final abundances were then averaged into 1-m depth intervals.

\subsection{Rate Measurements}

Rates of biological productivity was quantified using three different methods, as each technique yields different estimates of productivity. Net primary productivity (NPP), the difference between total photosynthesis and autotrophic respiration, was quantified by ${ }^{14} \mathrm{C}$-incubations and a bio-optical model. Strengths of this method are that direct ${ }^{14} \mathrm{C}$-uptake quantifies net productivity throughout the water column at the time and 

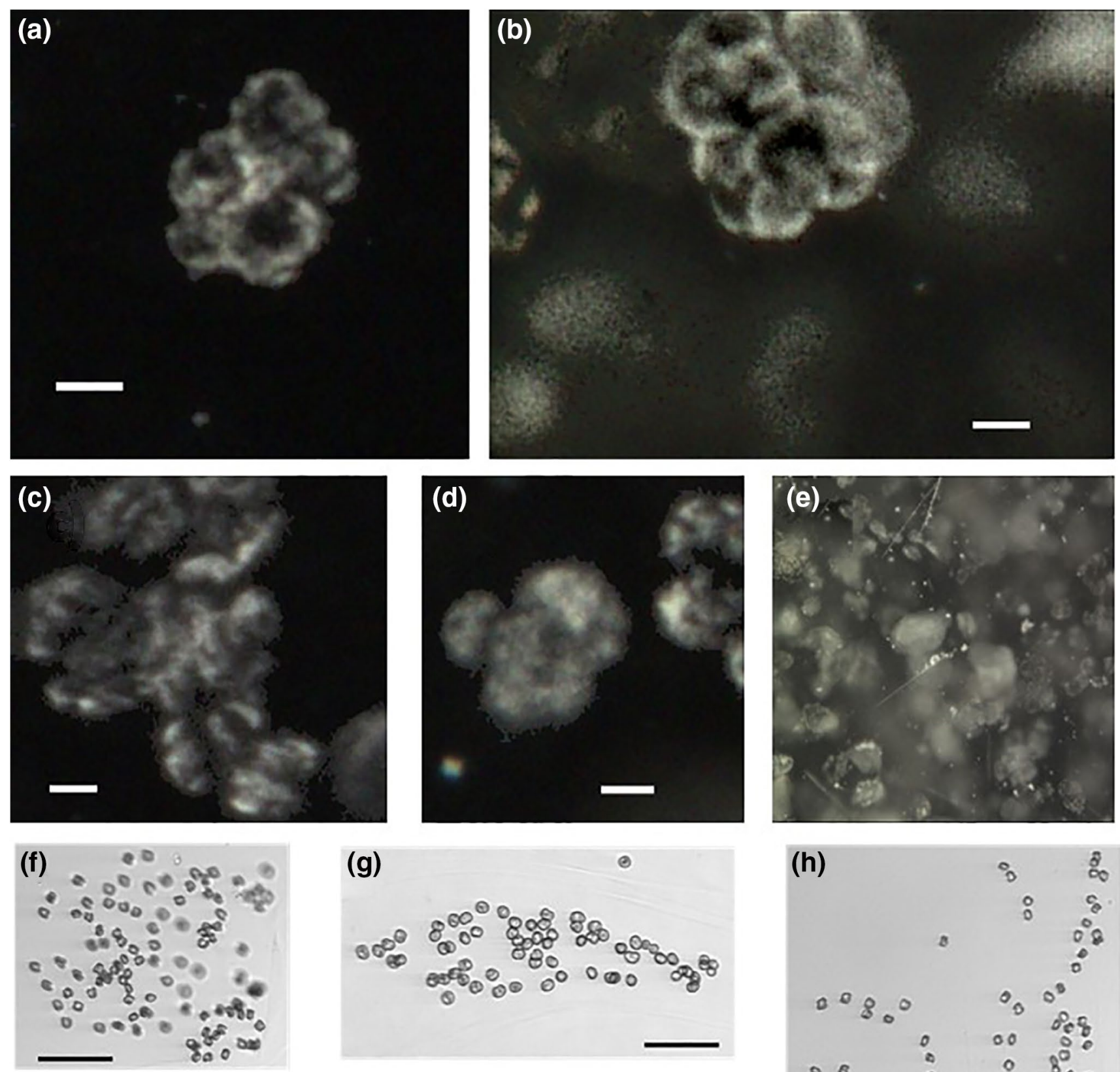

(g)

(2)
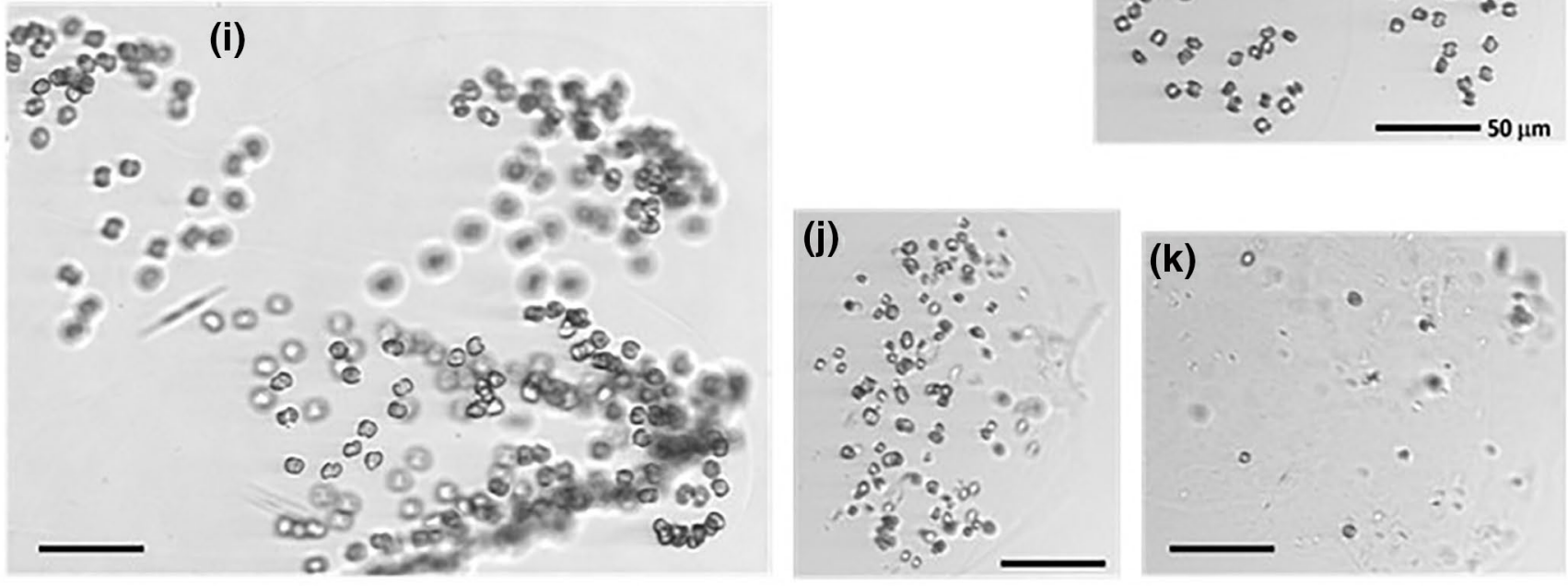
place the sample was collected, with no assumptions about physical transport. However, there were a limited number of direct ${ }^{14} \mathrm{C}$-measurements. Thus, the ${ }^{14} \mathrm{C}$-data were augmented with a bio-optical model that could be applied at all stations to gain greater spatial coverage of NPP. Net community production (NCP) is the difference between total photosynthesis and autotrophic and heterotrophic respiration and is most directly related to carbon export. Mixed layer integrated NCP was quantified through $\mathrm{O}_{2} / \mathrm{Ar}$ measurements, made both by a shipboard mass spectrometer and from discrete samples collected at the stations. Advantages of the $\mathrm{O}_{2} / \mathrm{Ar}$ method include the extremely dense sample coverage (data every few $\mathrm{km}$ along the entire cruise track) and the integrative nature of the measurement, allowing an assessment of how the bloom impacted the region on a one- to two-week timescale. Limitations include influences from physical transport of the gas tracers. Gross primary production (GPP) was quantified from triple oxygen isotope samples. GPP data provide information on the maximal possible production and reflects the total energy entering the ecosystem, and thus give useful supplemental information to NPP and NCP.

Phytoplankton photosynthetic carbon assimilation was measured using simulated in situ incubators and ${ }^{14}$ C-uptake (e.g., Smith et al., 2000). Water was collected from known isolumes (determined by the PAR sensor on the CTD-rosette) and placed into sterile 280-mL Qorpak bottles. Approximately $20 \mu \mathrm{Ci} \mathrm{NaH}{ }^{14} \mathrm{CO}_{3}$ $(\mathrm{pH}=9.6)$ were added to each bottle; the bottles were then placed in Plexiglas tubes wrapped with blue and neutral density screening to simulate the irradiance from which samples were collected in a deck incubator. Surface seawater flowed through the incubator to maintain ambient water temperatures. After a 24-h incubation, samples were removed and filtered through GF/F filters, which were placed in scintillation vials to which $5 \mathrm{~mL}$ Ecolume ${ }^{\circledR}$ scintillation cocktail was added, placed in darkness for $24 \mathrm{~h}$, and counted on a Beckman liquid scintillation counter. Total added isotope was determined by counting an unfiltered $0.1 \mathrm{~mL}$ sample in $0.1 \mathrm{~mL} \beta$-phenethylamine. Photosynthesis-irradiance responses were determined with similar methods, but water from one depth was used for all irradiance levels. Photosynthesis-irradiance incubations lasted $\sim 6 \mathrm{~h}$ and were conducted from morning through noon.

Primary productivity at inshore stations was also estimated using a bio-optical model. Details are provided in the Supplemental Material. The model was based on the formulation of Behrenfeld and Falkowski (1997a, 1997b) that combined vertical profiles of temperature, fluorescence, and PAR, along with a global temperature-photosynthesis response and the depth of the euphotic zone. We measured PAR on all CTD casts; when casts occurred at night, we estimated euphotic depths using the relationships of Morel (1998). Surface PAR was measured continuously by a quantum sensor (BioSpherical Model 240).

During both AR28B and AR29, water samples for dissolved oxygen and argon concentrations and triple oxygen isotopes were collected from the Niskin bottles and drawn into custom-made, prepoisoned, evacuated flasks (Emerson et al., 1991). Samples were collected at stations both within the Phaeocystis bloom and outside of it. The samples were subsequently measured on shore on the triple oxygen isotope processing line and isotope ratio mass spectrometer at WHOI (Stanley et al., 2015). Sample precision on that system is better than 6 per meg for ${ }^{17} \Delta \mathrm{O}, 0.01$ per mil for $\delta^{17} \mathrm{O}$, and 0.008 for $\delta^{18} \mathrm{O}$. Gross primary production was determined using the triple oxygen isotope ratio of dissolved oxygen, since photosynthesis results in mass dependent fractionation, whereas stratospheric processes lead to mass independent fractionation of $\mathrm{O}_{2}$ during gas exchange (Juranek \& Quay, 2013; Luz \& Barkan, 2000). Samples $(N=322)$ were collected from the surface and up to five additional depths to obtain detailed spatial resolution. At seven times during the cruise, samples were collected simultaneously from the surface Niskin of the CTD and the underway water to confirm that a significant amount of respiration was not occurring in the ship's lines and that the underway water was a good representation of the surface ocean gas content.

Net community production (NCP) was calculated from $\mathrm{O}_{2} / \mathrm{Ar}$ ratios determined on the same samples as the triple oxygen isotopes (sample precision $=0.2$ per mil). Additionally, NCP was calculated from $\mathrm{O}_{2} /$ Ar measured by an Equilibrator Inlet Mass Spectrometer (EIMS) from the ship's underway system (intake depth $=2.1 \mathrm{~m}$ ) with a precision of $0.2 \%$ on a timescale of seconds to minutes, thus providing spatial res-

Figure 2. Typical DAVPR images of (a) a solitary Phaeocystis colony, (b-d) multiple Phaeocystis colonies, and (e) multiple colonies that made counting impractical. The white bar represents $300 \mu \mathrm{m}$. With their higher resolution, typical IFCB images show individual Phaeocystis cells within (f-j) colonies and colony fragments, as well as (k) colony debris with few if any visible cells. The black bar represents $50 \mu \mathrm{m}$. 
olution of several kilometers. The EIMS operated the entire cruise and thus provides thousands of NCP measurements both within the Phaeocystis bloom and outside of it. The EIMS followed the design of Cassar et al. (2009) with the following modifications: a Hiden RGA analyzer (model HAL 3F 301 RC, dual Faraday/Single channel electron multiplier detector) was used; the equilibrator cartridge (Membrana Liqui-Cel Extra Flow 2.5 x8, X40 fiber) was significantly larger than the one used in Cassar et al. (2009); a drying loop with a nafion dessicant box, a $\sim 20 \mathrm{~cm}$ length of $1 / 4$ " ID tubing filled with drierite, and a microdiaphragm pump for gas recirculation were added to fully dry the gas stream from the cartridge and achieve faster equilibration of gases (Manning et al., 2016). Discrete samples collected from the underway system were compared to the EIMS to confirm equilibration of the EIMS.

Gross oxygen photosynthesis (GOP) in the mixed layer was calculated from $\delta^{17} \mathrm{O}$ and $\delta^{18} \mathrm{O}$ triple oxygen isotope samples (Prokopenko et al., 2011), assuming steady-state and neglecting horizontal mixing. The gas transfer velocity, required for the calculations, was calculated using a weighted 60-day average (Reuer et al., 2007) of NCEP Reanalysis winds (Kalnay et al., 1996). The calculations used a respiration slope of $\lambda=0.5179$, a photosynthetic $\mathrm{O}_{2}$ of average phytoplankton (Barkan \& Luz, 2011), and water isotope end members of Vienna Standard Mean Ocean Water (VSMOW). The $\delta^{18} \mathrm{O}-\mathrm{H}_{2} \mathrm{O}$ of selected samples $(N=14)$ was measured and the differences from VSMOW mean that the total error to GOP from the water isotopic value is less than 10\% (Manning et al., 2016).

Rates of NCP integrated over the mixed layer were calculated from the continuous and discrete $\mathrm{O}_{2} / \mathrm{Ar}$ data using the equation

$$
\mathrm{NCP}=\left[\left(\mathrm{O}_{2} / \mathrm{Ar}\right)_{\text {meas }} /\left(\mathrm{O}_{2} / \mathrm{Ar}\right)_{\mathrm{eq}}-1\right] \times \mathrm{O}_{2 \mathrm{eq}} \times k \times \rho
$$

where $\left(\mathrm{O}_{2} / \mathrm{Ar}\right)_{\text {meas }}$ is the $\mathrm{O}_{2} /$ Ar ratio as measured by the EIMS, $\left(\mathrm{O}_{2} / \mathrm{Ar}\right)_{\text {eq }}$ is the ratio of $\mathrm{O}_{2}$ to Ar equilibrium concentrations, $\mathrm{k}$ is the gas transfer velocity, $\rho$ is the density of seawater, and $\mathrm{O}_{2 \mathrm{eq}}$ is the equilibrium concentration of $\mathrm{O}_{2}$ at the temperature and salinity of the sample (Hendricks et al., 2004). $\mathrm{O}_{2}$ equilibrium values were calculated according to Garcia and Gordon (1992) and Ar equilibrium values were calculated according to Hamme and Emerson (2004). These NCP calculations assumed steady state and neglected lateral advection.

Although the mixed layer $\mathrm{O}_{2}$ isotopes and $\mathrm{O}_{2} / \mathrm{Ar}$ ratios were likely not truly at steady state, the steady-state assumption means that the NCP and GOP rates calculated provide an integrated productivity rate over a time scale of several days to two weeks (mean $=6$ days), given by the ratio of the gas transfer velocity to mixed layer depth (Nicholson et al., 2014; Teeter et al., 2018). These integrated rates thus reflect the time-weighted average productivity from one to two weeks and indicate how the bloom affected local productivity before the samples were collected. For example, even though the rates are for mixed layer only, we see significant mixed layer increases in NCP in Phaeocystis-dominated stations compared to a nonbloom year, in part because the rates are reflecting the early time period when Phaeocystis was in the mixed layer. Even though horizontal advection undoubtedly occurred, lateral gradients of measured gas tracers as well as the satellite pigment data suggest that the elevated chlorophyll on the shelf remained for multiple days and that low horizontal mixing was occurring.

\subsection{Satellite Imagery}

Satellite-retrieved sea surface temperature and chlorophyll concentration data with spatial resolution of about $1.8 \mathrm{~km}$ were obtained from the Moderate Resolution Imaging Spectroradiometer (MODIS Aqua) Level-3 standard mapped data set with a horizontal resolution of $4 \mathrm{~km}$ (https://modis.gsfc.nasa.gov) using ERDDAP (http://basin.ceoe.udel.edu/erddap/).

\section{Results}

\subsection{In Situ Observations}

On April 3, temperatures were less than $4.5^{\circ} \mathrm{C}$ at the surface inshore and increased offshore (Figure 3a). On April 23, the very low temperatures had disappeared, replaced by a thin layer of warmer water $\left(>6^{\circ} \mathrm{C}\right)$ associated with springtime stratification (Figure 3c). Surface temperatures increased through time, reaching $8^{\circ} \mathrm{C}$ and 

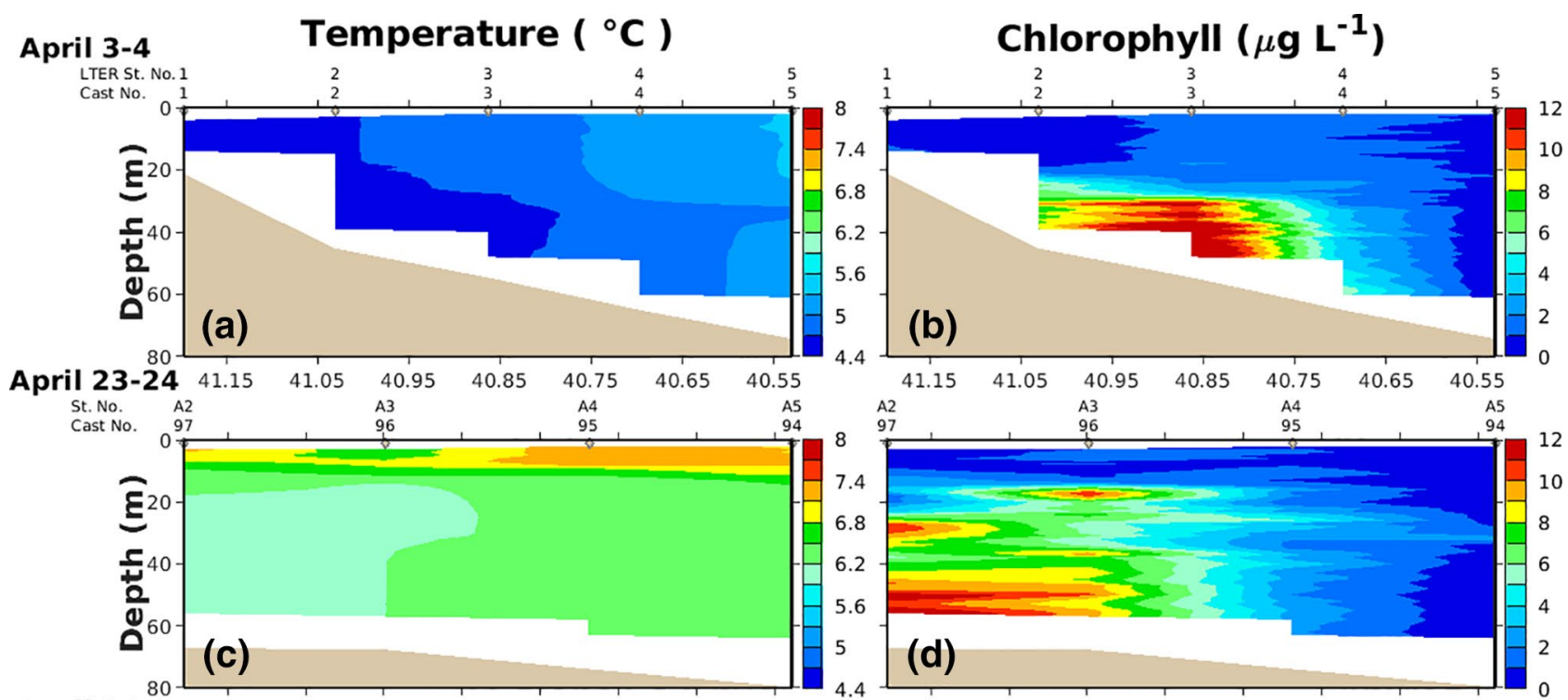

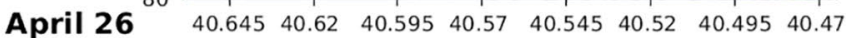

$\begin{array}{lc}\text { St. No. } & \text { A2 } \\ \text { Cast No. } & 129\end{array}$

A3 128

A4 126

A5 125

$\begin{array}{llllllll}40.645 & 40.62 & 40.595 & 40.57 & 40.545 & 40.52 & 40.495 & 40.47\end{array}$
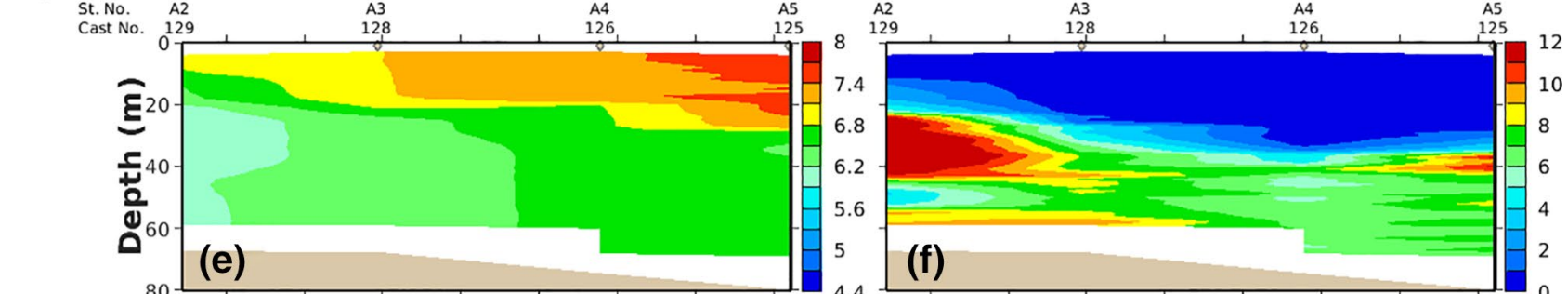

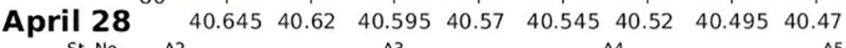
St. No.

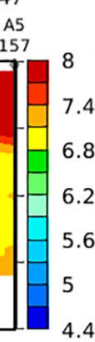

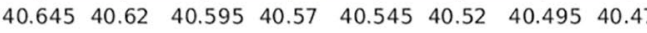

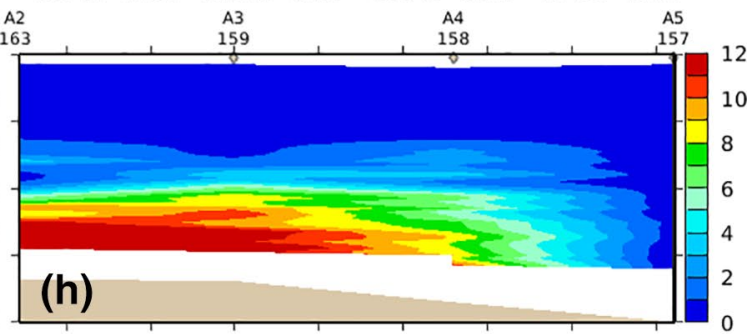

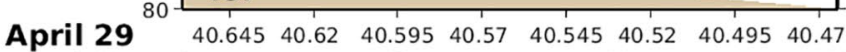

$\begin{array}{llllllll}40.645 & 40.62 & 40.595 & 40.57 & 40.545 & 40.52 & 40.495 & 40.47\end{array}$

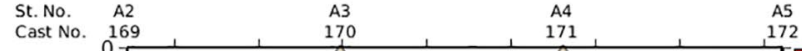

A5 172

A2
169

A3

A4
171

A5
172
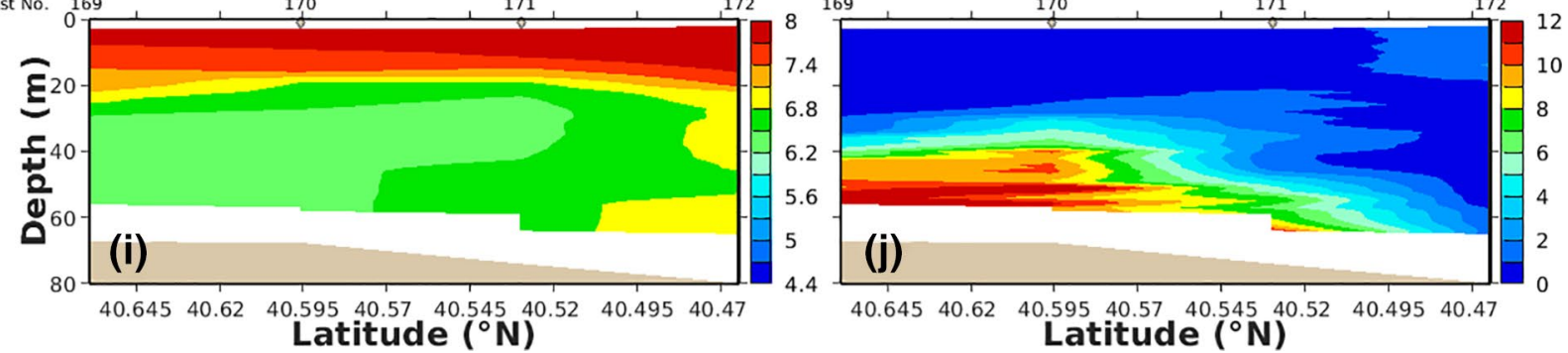

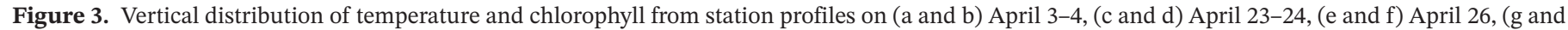

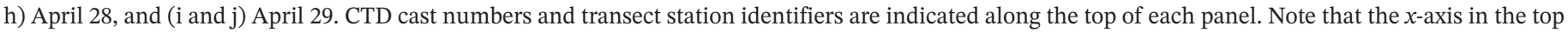

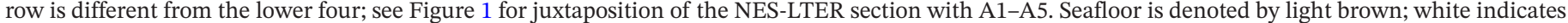

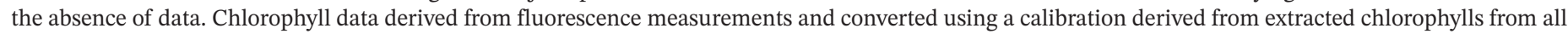
stations. 
Table 1

Integrated Chlorophyll and Particulate Organic Carbon Concentrations

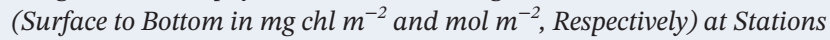
$A 2, A 3, A 4$, and $A 5$

\begin{tabular}{|c|c|c|c|c|c|c|c|c|}
\hline \multirow[b]{2}{*}{ Location/date } & \multicolumn{4}{|c|}{ Chlorophyll } & \multicolumn{4}{|c|}{ Particulate organic carbon } \\
\hline & A2 & A3 & A4 & A5 & A2 & A3 & A4 & A5 \\
\hline April 21 & - & - & - & 84.3 & - & - & - & 0.65 \\
\hline April 23-24 & 351 & 300 & 161 & 79.5 & 1.82 & 1.39 & 0.54 & 0.32 \\
\hline April 26 & 464 & 281 & 265 & 354 & 0.83 & 1.07 & 1.14 & 1.51 \\
\hline April 28 & 325 & 238 & 237 & 56.4 & 1.36 & 1.13 & 1.16 & 0.35 \\
\hline April 29 & $234^{\mathrm{a}}$ & - & - & $171^{\mathrm{b}}$ & $1.43^{\mathrm{a}}$ & - & - & $2.25^{\mathrm{b}}$ \\
\hline
\end{tabular}

${ }^{\mathrm{a}}$ Integration depth $40 \mathrm{~m}$. ${ }^{\mathrm{b}}$ Integration depth $35 \mathrm{~m}$. above (Figure 3i). Inshore chlorophyll levels were elevated during all occupations, particularly at depth (Figure 3 ). Relatively low chlorophyll concentrations $\left(<2 \mu \mathrm{g} \mathrm{L}^{-1}\right)$ were observed at all locations; these occurred over a clear subsurface maximum below $\sim 20 \mathrm{~m}$ on April 23-24. Two days later (April 26) inshore chlorophyll significantly increased (nearly doubling) and was maximal near $35 \mathrm{~m}$. This high chlorophyll bolus was confined to the most inshore location, and over the next few days became associated with the bottom boundary layer. Its horizontal dimension also increased slightly offshore. Chlorophyll at Station A5 on April 21 was $<2 \mu \mathrm{g} \mathrm{L}^{-1}$ in the upper $30 \mathrm{~m}$, and decreased to near zero at $55 \mathrm{~m}$; the next profile at the same site was similar, with a slight increase at $25 \mathrm{~m}$. On April 26, however, the vertical profile was radically different: low concentrations $\left(\sim 0.5 \mu \mathrm{g} \mathrm{L}^{-1}\right)$ were noted at the surface, and a large increase in the mid-water column was observed, with a decrease below that (Figure 3d). Similar midwater maxima farther inshore were noted on April 26, but thereafter the maximum chlorophyll concentrations occurred near the bottom.

Integrated water column chlorophyll concentrations also changed in space and time (Table 1). There was a strong gradient in total chlorophyll from inshore to offshore, with Station A2 having the largest biomass. Chlorophyll levels there were from 3 to 10 times those measured at Station A5. In addition to the spatial gradient, a temporal pattern was observed, especially in the more inshore stations. At Station A2 integrated chlorophyll increased between the first and second occupation (2 days after), but decreased dramatically (by $52 \%$ from 413 to $199 \mathrm{mg} \mathrm{m}^{-2}$ ) between the second and third sampling (2 days between sampling). In contrast, Station A5 over the same time intervals increased from 37.4 to $77.1 \mathrm{mg} \mathrm{m}^{-2}$.

The time series of nutrients at the outermost location on the transect (Station A5) indicated a substantial removal of nutrients during the short intervals sampled. Nitrate + nitrite concentrations at the surface were $\sim 6 \mu \mathrm{M}$ on April 21 and 23, but decreased to $\sim 3 \mu \mathrm{M}$ by April 26 (Figure 4a), suggesting Phaeocystis was utilizing nitrate for growth. Concentrations increased throughout the water column on April 28 (Cast 157) to levels similar to those at the first two casts. Ammonium concentrations were approximately $1 \mu \mathrm{M}$ initially, but also decreased at Station A5 along with nitrate + nitrite (Figure 4a). Silicic acid concentrations were $\sim 5 \mu \mathrm{M}$ initially, but also decreased (by $\sim 2 \mu \mathrm{M}$ ) by April 26 (Figure $4 \mathrm{~b}$ ). Unlike nitrate, silicic acid remained low through $60 \mathrm{~m}$ on April 28. Uptake ratios of nitrate and phosphate (calculated from reductions from data collected on April 23-24 and April 26; data not shown) averaged 20.4 for the entire water column, considerably above the canonical Redfield ratio of 16 .

Vertical nutrient distributions of the inshore stations (A2-A4) were considerably different than that at Station A5 (Figures 4c-4h). On April 23 (A2, the most inshore station), nitrate + nitrite concentrations were below $1 \mu \mathrm{M}$ in the upper $15 \mathrm{~m}$ at all casts, and increased to above $2 \mu \mathrm{M}$ near $30 \mathrm{~m}$ (Figure $4 \mathrm{~g}$ ). Ammonium levels were between 0.4 and $1.6 \mu \mathrm{M}$ at all depths. $\mathrm{Si}(\mathrm{OH})_{4}$ concentrations were less variable and varied by less than $1 \mu \mathrm{M}$ throughout the water column. On April 26 at Station A3, nitrate + nitrite was initially reduced to $<0.2 \mu \mathrm{M}$ in the upper $10 \mathrm{~m}$, but increased through April 29 by 1-2 $\mu \mathrm{M}$ in the upper $20 \mathrm{~m}$ (Figure 4e). Ammonium again did not vary greatly throughout the water column. Silicic acid vertical distributions were similar to those at Station A2 and also did not vary substantially (Figure 4f). On April 26 Station A4 nitrate + nitrite levels were somewhat higher in the upper $20 \mathrm{~m}$ than farther inshore (between 1 and $2 \mu \mathrm{M}$ ), and by April 29, a marked midwater minimum was observed at $22 \mathrm{~m}$; ammonium levels again did not vary substantially (Figure $4 \mathrm{c}$ ). $\mathrm{Si}(\mathrm{OH})_{4}$ concentrations were elevated on April 23, but were reduced during the following 5 days by $\sim 2 \mu \mathrm{M}$ (Figure $4 \mathrm{~d}$ ).

Particulate organic carbon and nitrogen distributions paralleled those of chlorophyll (Table 1). Maximum POC and PON concentrations were 95.7 and $10.7 \mu \mathrm{mol} \mathrm{L}^{-1}$, respectively (data not shown); mean POC and PON concentrations at the stations where Phaeocystis was abundant were 18.3 and $2.57 \mu \mathrm{mol} \mathrm{L}^{-1}$, giving a mean molar $\mathrm{C} / \mathrm{N}$ ratio of 7.12 and a mean carbon:chlorophyll ratio of $56.2(\mathrm{w} / \mathrm{w})$.

Estimates of Phaeocystis colonies from the DAVPR showed the temporal evolution of the bloom and the contribution of colonies to overall biomass (Figure 5). Maximum abundance of colonies on April 19 was $0.4 \mathrm{~mL}^{-1}$ and increased to over $0.6 \mathrm{~mL}^{-1}$ during later surveys (e.g., April 23 and later). The greatest 
(a)

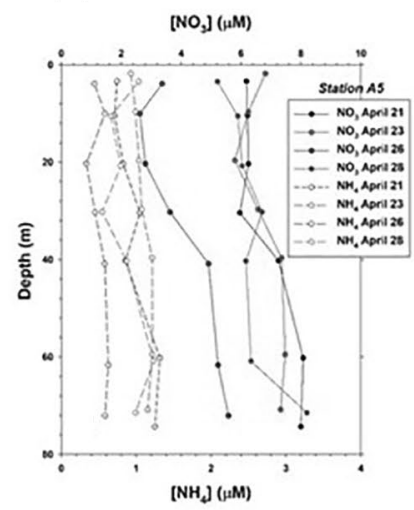

(c)

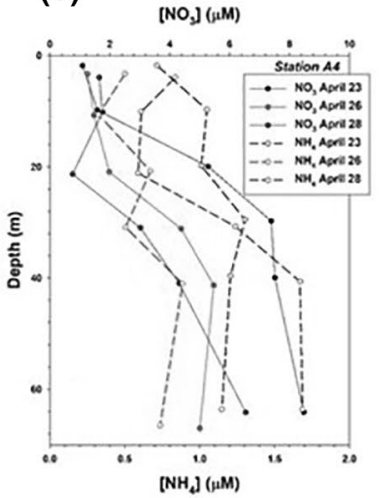

(b)

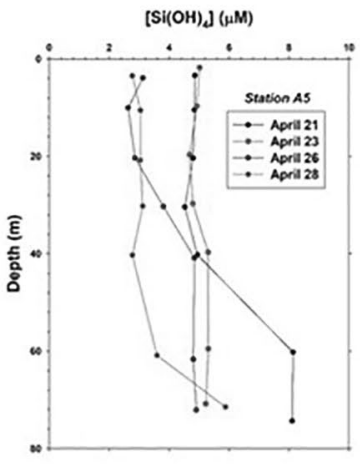

(d)

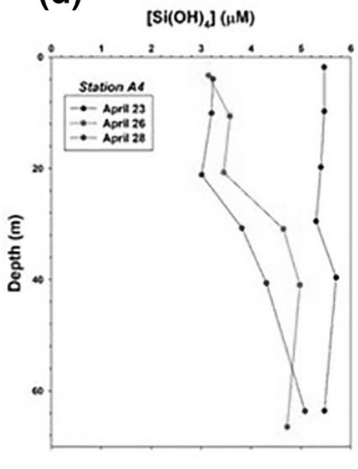

(e)

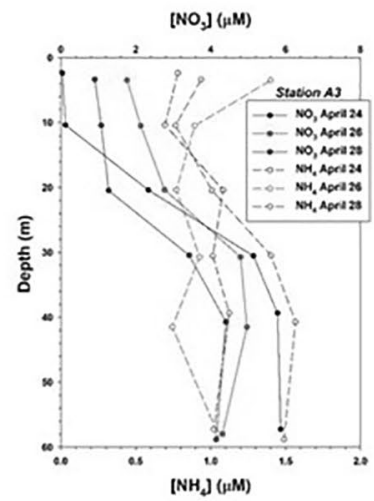

(g)

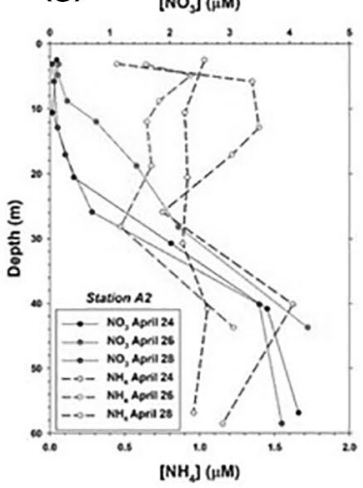

(f)

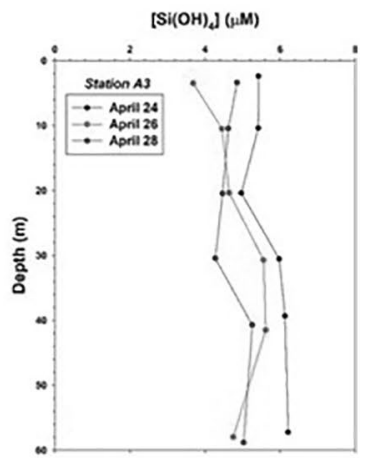

(h)

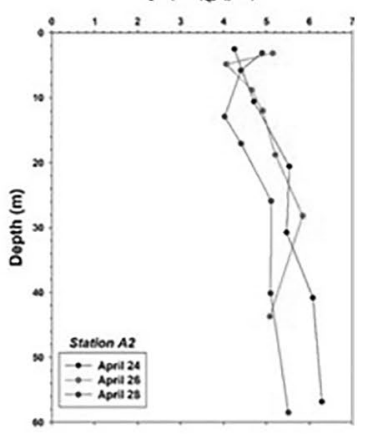

Figure 4. Time series of vertical nitrate + nitrite and ammonium distributions at (a) Station A5, (c) Station A4, (e) Station A3, and (g) Station A2, and of silicic acid concentrations at (b) Station A5, (d) Station A4, (f) Station A3, and (h) Station A2. Nitrate + Nitrite sampling dates indicated by N + N.

abundances were noted on the continental shelf, but colonies also were observed in deeper waters as well (data not shown). During April 23 colonies were observed throughout much of the water column, but after April 26 maximum abundances were observed in deeper waters. On April 27 and 28 colonies were largely absent in the upper $10 \mathrm{~m}$, but highly concentrated near the bottom.

Satellite observations obtained at sea suggested the Phaeocystis bloom was contiguous with an area of high chlorophyll present on Nantucket Shoals. To verify this, a spatial survey was conducted from the main sampling transect eastward into the area of high chlorophyll detected by satellites using a towed VPR (Davis et al., 2005) undulating between the surface and $\sim 20 \mathrm{~m}$ off the bottom. In the beginning of the survey, Phaeocystis colonies were confined mostly to the bottom boundary layer. Farther east, colonies became more abundant throughout the water column, at times creating such high backscatter that the VPR images would become saturated-making discrimination of individual colonies impossible (Figure 2e). A DAVPR profile was occupied at the endpoint of the eastward transect on April 28 (Cast 167; Figure 1), facilitating direct comparison with Phaeocystis concentrations observed on the main transect (Figure 6). Cast167 had a relatively broad maximum between 16 and $29 \mathrm{~m}$ (and decreasing below that), in contrast to the pattern at Station 2 on April 28 (Cast 163), which exhibited a maximum in the bottom boundary layer. Counts obtained from the IFCB are also included (Figure 6).

\subsection{When Did the Bloom Begin?}

Our ship-board in situ sampling was confined to a relatively short period in April, but the bloom was followed by other means to establish a timeline of appearance. Satellite images on January 27 of temperature (Figure 7) and chlorophyll (Figure 8) suggested a substantial accumulation of chlorophyll in regions with low $\left(<6^{\circ} \mathrm{C}\right)$ sea surface temperatures. Additionally, colonies of Phaeocystis were observed at the MVCO in 

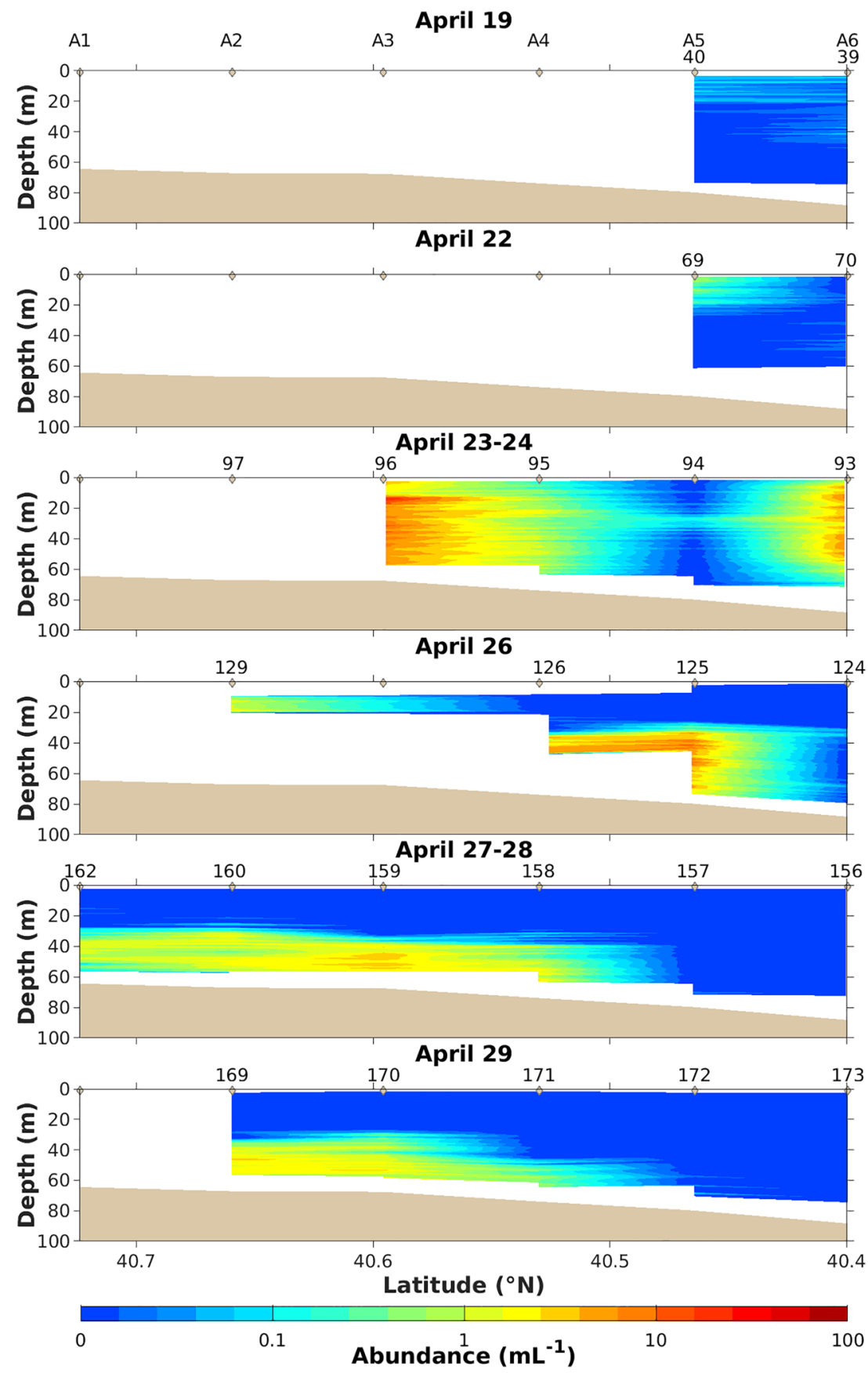

Figure 5. Distribution of Phaeocystis abundance (note log scale) through time across the continental shelf as determined from the DAVPR. Concentrations shown for stations A1-A6 (left to right as diamonds) plotted as averages for 5-m depth bins. Light brown area denotes the sea floor. DAVPR: Digital Autonomous Video Plankton Recorder.

mid-January (Figure 9). As such, it is reasonable to conclude that the enhanced chlorophyll found on the inner continental shelf was partially or largely driven by accumulation of Phaeocystis.

Surface chlorophyll concentrations continued to be elevated from February through April, and were largely associated with waters with cold temperatures (Figures 7 and 8). In early January, there was a significant negative correlation of surface temperature and chlorophyll that weakened and disappeared as waters warmed (Figure S1), suggesting that Phaeocystis was acclimated to cold waters. Furthermore, high chloro- 
(a) Phaeocystis colony abundance $\left(\mathrm{mL}^{-1}\right)$

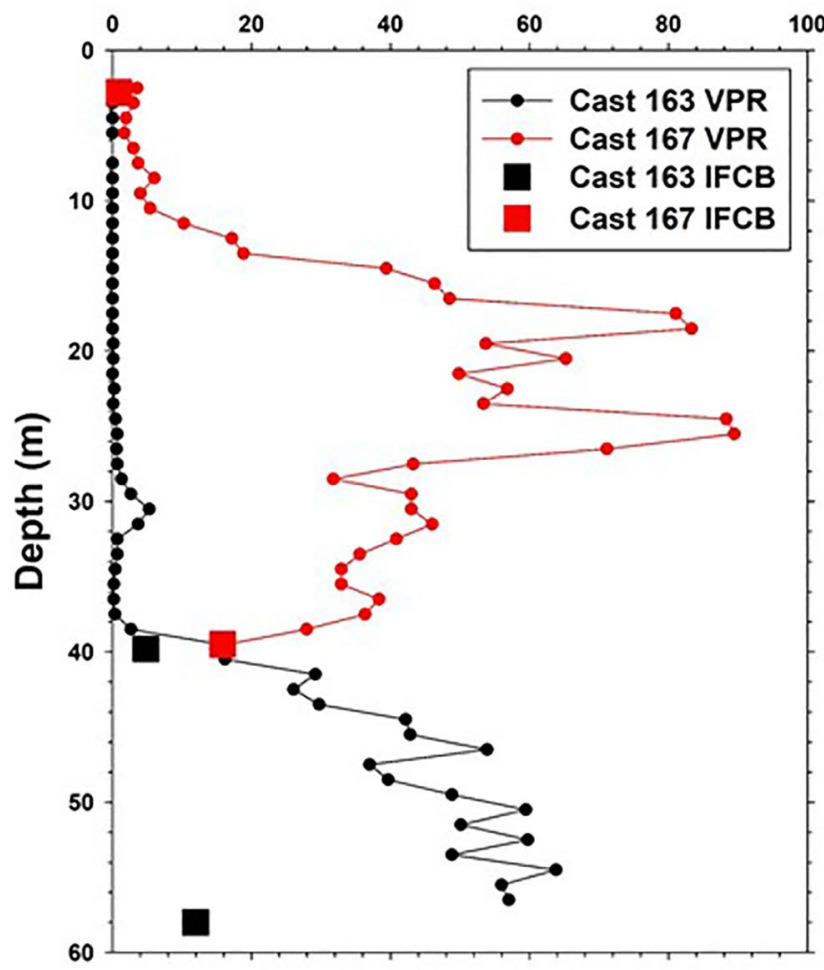

(b) Chlorophyll ( $\left.\mu \mathrm{g} \mathrm{L}^{-1}\right)$

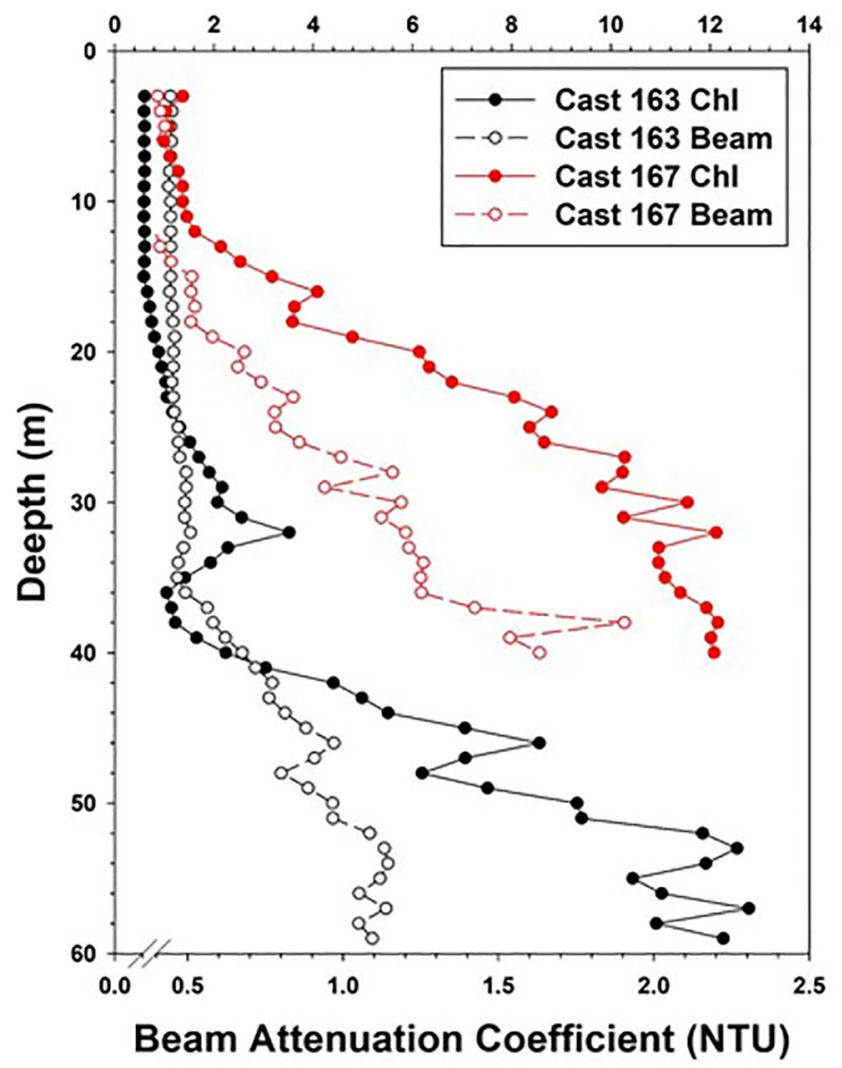

Figure 6. (a) DAVPR Phaeocystis colony concentrations on the main transect (Cast 163, Station A2) and during a survey to the west (Cast $167,40.65^{\circ} \mathrm{N}$, $70.25^{\circ} \mathrm{W}$ ). Abundance was determined by counting the number of Phaeocystis pouchetii colonies in each individual ROI. Counts from the IFCB collected on the same casts are included for comparison. (b) Chlorophyll (Chl) concentrations and beam attenuation coefficient (Beam) at the same two casts, indicating the substantial contribution of Phaeocystis to the total particulate load. Beam attenuation coefficients are in nephelometric turbidity units. DAVPR: Digital Autonomous Video Plankton Recorder; IFCB: Imaging Flow Cytobot; ROI: regions of interest.

phyll locations were generally associated with waters $<6^{\circ} \mathrm{C}$. Over the same time period, air temperatures and solar radiation generally increased, while the winds fluctuated with the passage of storm events (Figure 10). By April 24, the bloom's surface area covered approximately 8,000 $\mathrm{km}^{2}$. On April 25, surface chlorophyll levels decreased, and the signature of cold, coastal water nearly disappeared (Figures 7 and 8). The surface expression of the bloom had largely disappeared by May 11.

\subsection{Productivity Estimates}

Primary productivity was measured by carbon uptake in simulated in situ incubations at only one of the stations reported in this paper (Cast 129 at Station 2, April 26; integrated productivity $=1.08 \mathrm{~g} \mathrm{C} \mathrm{m}^{-2} \mathrm{~d}^{-1}$ ) due to sampling at times inappropriate for incubations, but a bio-optical model was constructed to estimate productivity at all stations using the measured PAR data (Table 2). Daily modeled productivity averaged $0.36 \pm 0.19 \mathrm{~g} \mathrm{C} \mathrm{m}^{-2} \mathrm{~d}^{-1}$ (integrated through the $1 \%$ isolume). From estimates of the contribution of $P$. pouchetii to chlorophyll concentrations, Phaeocystis contributed on average $23 \%$ of integrated productivity (Supplemental Material). In addition, primary productivity was estimated from satellite productivity algorithms; monthly productivity for the bloom area in 2017 (a year with no Phaeocystis; Figure S2) and 2018 was nearly the same in January and February, but in March and April, it was 31\% and 121\% greater, respectively (Table S2). Euphotic zone depths within the bloom (Table 2) averaged $27.8 \pm 4.7 \mathrm{~m}$, indicating that irradiance penetrated to depth with photon fluxes high enough to support photosynthesis throughout much 

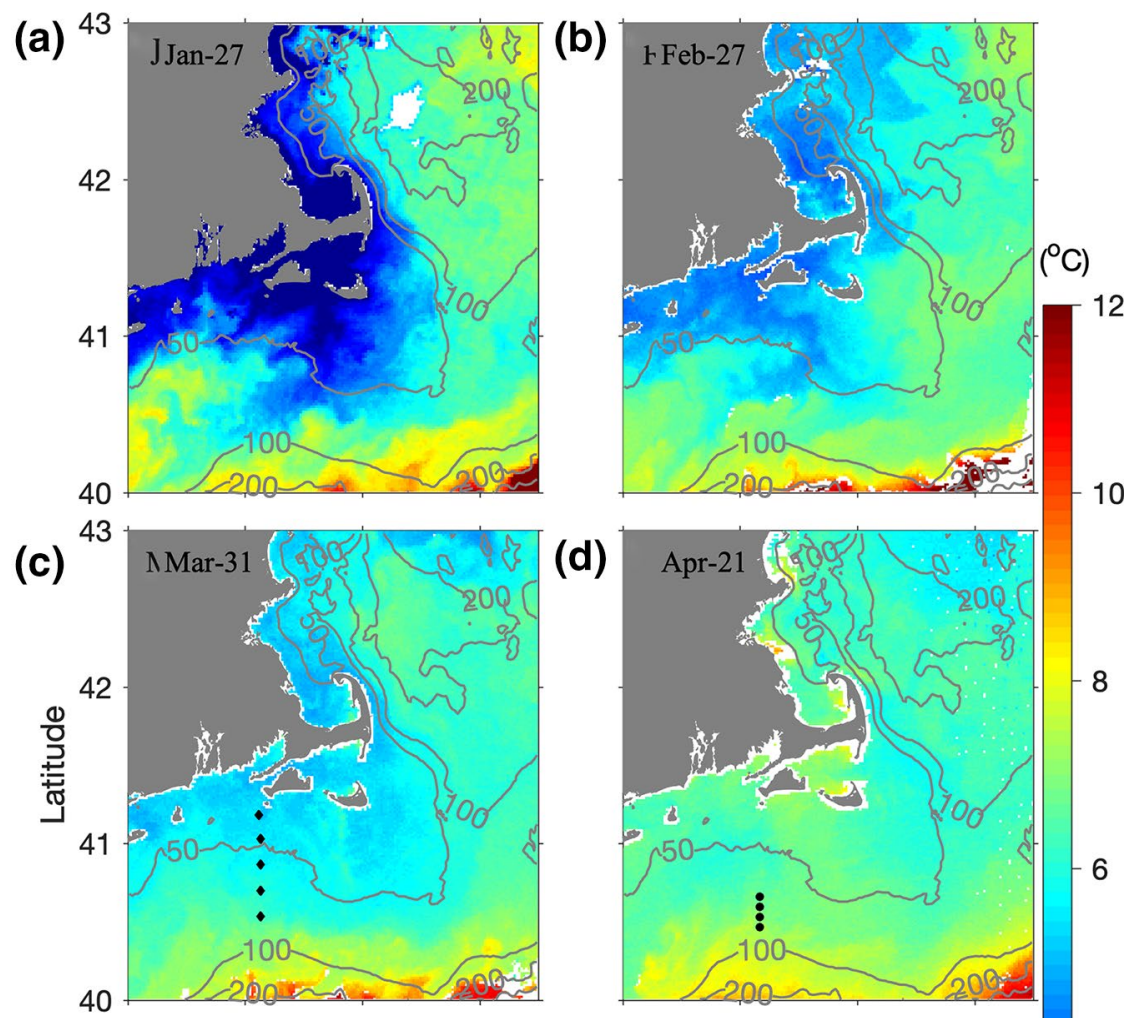

(d)

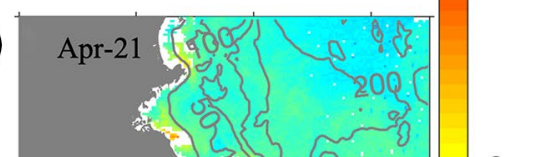

(e)

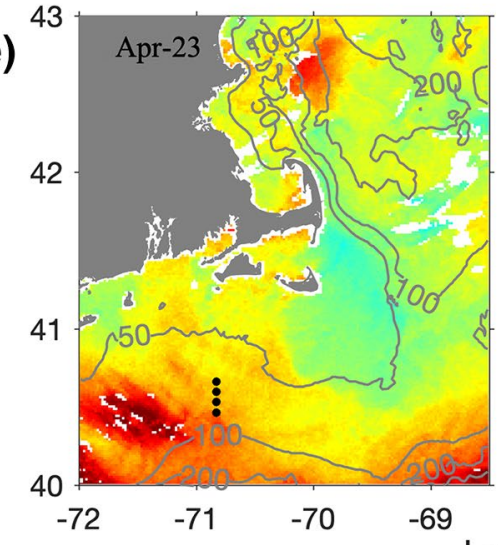

(f)

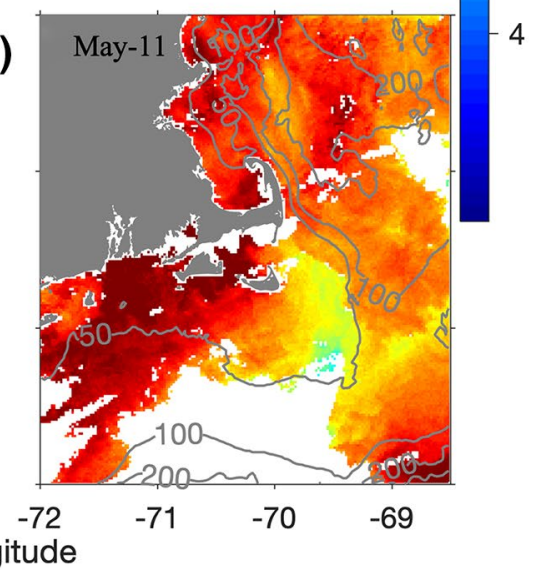

Figure 7. Distribution of sea surface temperature $\left({ }^{\circ} \mathrm{C}\right.$ ) on (a) January 26, (b) February 27, (c) March 31, (d) April 21, (e) April 23, and (f) May 11, 2018. Dots in (c) indicate the NES-LTER station locations, and those in (d and e) indicate the location of Stations A2-A5.

of the water column. Photosynthesis-irradiance responses were assessed using ${ }^{14} \mathrm{C}$-uptake at two locations where Phaeocystis was observed (Casts 129 and 162; sampled from 26 and $28 \mathrm{~m}$, the 1\% and 5\% isolumes; Figure 11). Estimated $P_{\max }^{B}$ and $\alpha$ values (using the measured PAR) were 1.2 and $1.6 \mathrm{mg} \mathrm{C}(\mathrm{mg} \mathrm{chl})^{-1} \mathrm{~h}^{-1}$ and 0.048 and $0.044 \mu \mathrm{g} \mathrm{C}(\mu \mathrm{g} \mathrm{chl})^{-1} \mathrm{~h}^{-1}$ ( $\mu \mathrm{mol}$ photons $\left.\mathrm{m}^{-2} \mathrm{~s}^{-1}\right)^{-1}$, respectively.

NCP as estimated from continuous underway sampling within the mixed layer also showed noticeable spatial changes that coincided with changes in Phaeocystis abundance (Figure 12); NCP was higher in regions where significant numbers of Phaeocystis colonies were present. This was especially noticeable in the period of April 3-13 when the Phaeocystis were largely confined to the surface (Figure 12a). Later in April (Figure 12b), significant numbers of Phaeocystis were observed inshore, but NCP did not start increasing until about $41^{\circ} \mathrm{N}$. Further south, where Phaeocystis colonies were no longer abundant in the surface waters, but 
(a) 4

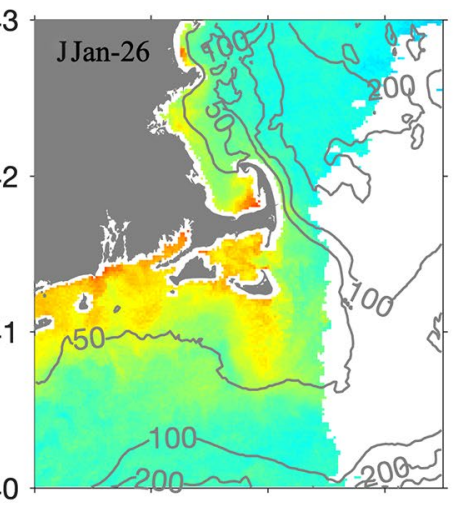

(c)

43

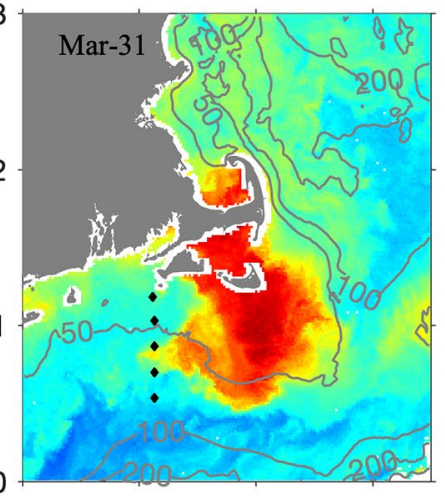

(e)

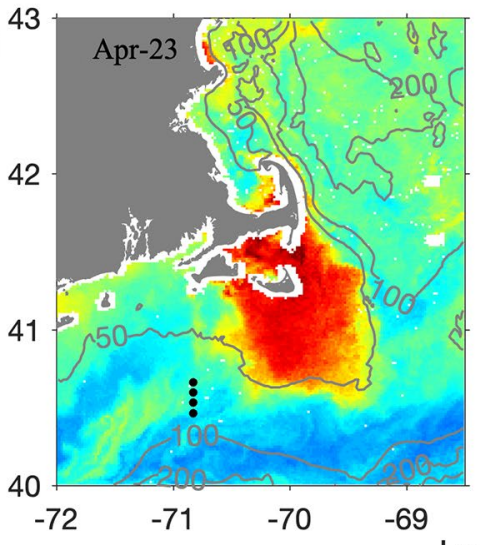

(b)

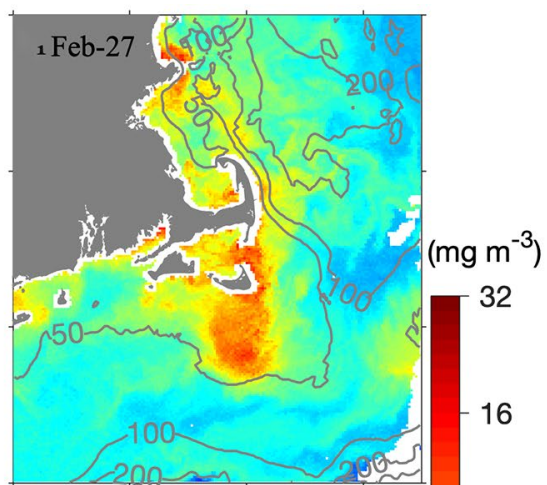

(d)

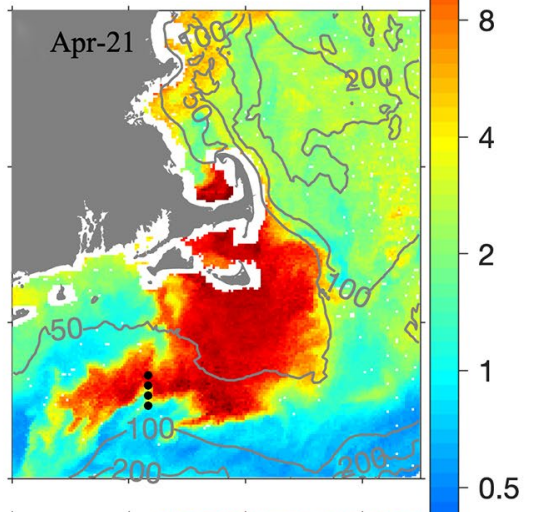

(f)

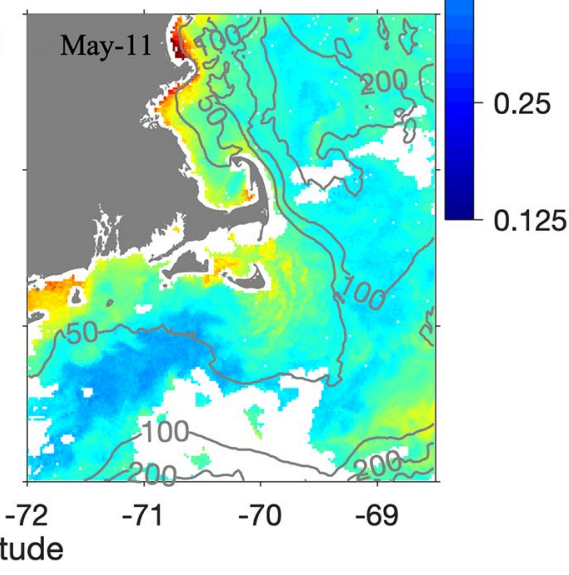

Figure 8. Distribution of satellite-derived sea surface chlorophyll on (a) January 26, (b) February 27, (c) March 31, (d) April 21, (e) April 23, and (f) May 11, 2018. Diamonds in (c) indicate the NES-LTER station locations, and dots in (d and e) indicate the location of Stations A2-A5.

still present in deeper waters, mixed layer NCP remained high. The eastward survey onto Nantucket Shoals revealed high NCP throughout, consistent with an ongoing Phaeocystis bloom in those waters. Additionally, NCP showed temporal changes (Figure S3), with the earliest transect having the greatest productivity, and $\mathrm{NCP}$ declining through time. The maximum $\mathrm{NCP}\left(185 \mathrm{mmol} \mathrm{O}_{2} \mathrm{~m}^{-2} \mathrm{~d}^{-1}\right)$ is equivalent to $1.58 \mathrm{~g} \mathrm{C} \mathrm{m}^{-2} \mathrm{~d}^{-1}$, substantially more than predicted from the bio-optical model. All values were positive, reinforcing the substantial autotrophic activity on the shelf.

GOP data are more limited than those of NCP, being measured at only a subset of stations, but also strongly indicate that productivity was elevated in the Phaeocystis bloom. GOP was $190 \%$ higher at stations A2 through A5 (Table 2) compared to stations further south where Phaeocystis was less abundant (Figure S4). 


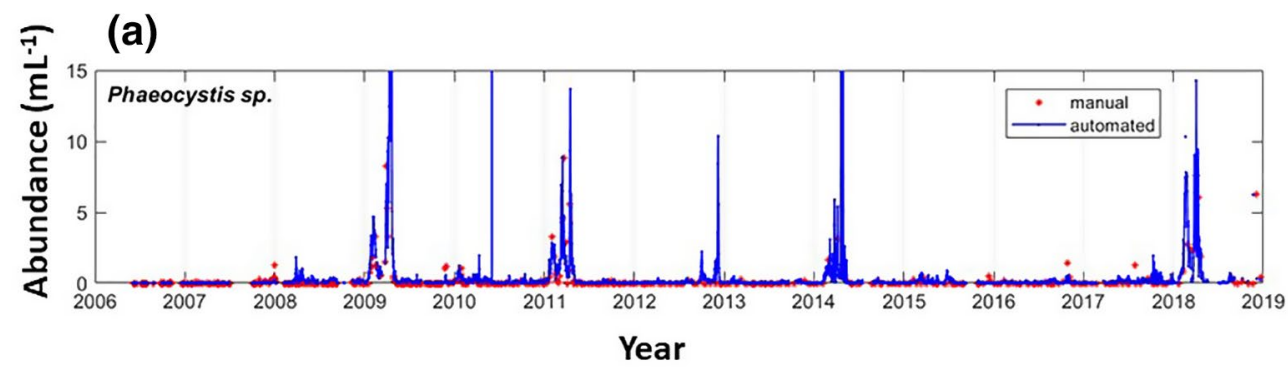

(b)

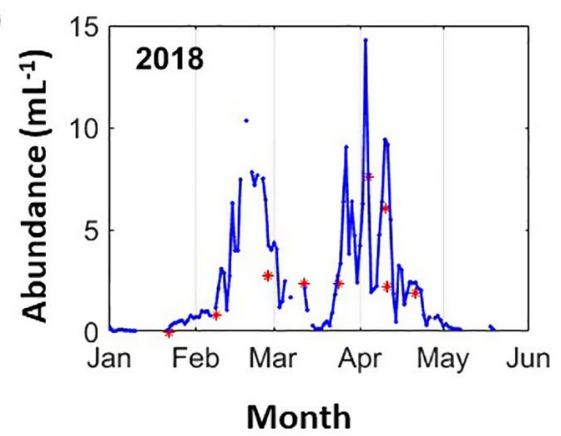

Figure 9. Time series of Phaeocystis colony abundances from automated IFCB imaging at the Martha's Vineyard Coastal Observatory. The blue line indicates daily abundances from classification of all images with a machine learning algorithm, and red asterisks show concentrations determined from manual classification of images for selected samples corresponding to approximately $1 \mathrm{~h}$ of data collection. (b) Same as in (a), but expanded to emphasize only the first six months of 2018. IFCB: Imaging Flow Cytobot.

\section{Discussion}

The Nantucket Shoals region where the Phaeocystis bloom was observed is an area of strong currents and complex physical structure (e.g., Limeburner \& Beardsley, 1982; Wilkin, 2006). Stratified waters from the Gulf of Maine flow through the Great South Channel and onto Nantucket Shoals. Strong tidal currents mix the entire water column on Nantucket Shoals before the water flows westward or northwestward following the isobaths along the New England shelf. The current on the shoal is likely uniform in much of the water column and has a speed of $\sim 0.1 \mathrm{~m} \mathrm{~s}^{-1}$ (Beardsley et al., 1985). This gives a residence time of $\sim 10$ days for

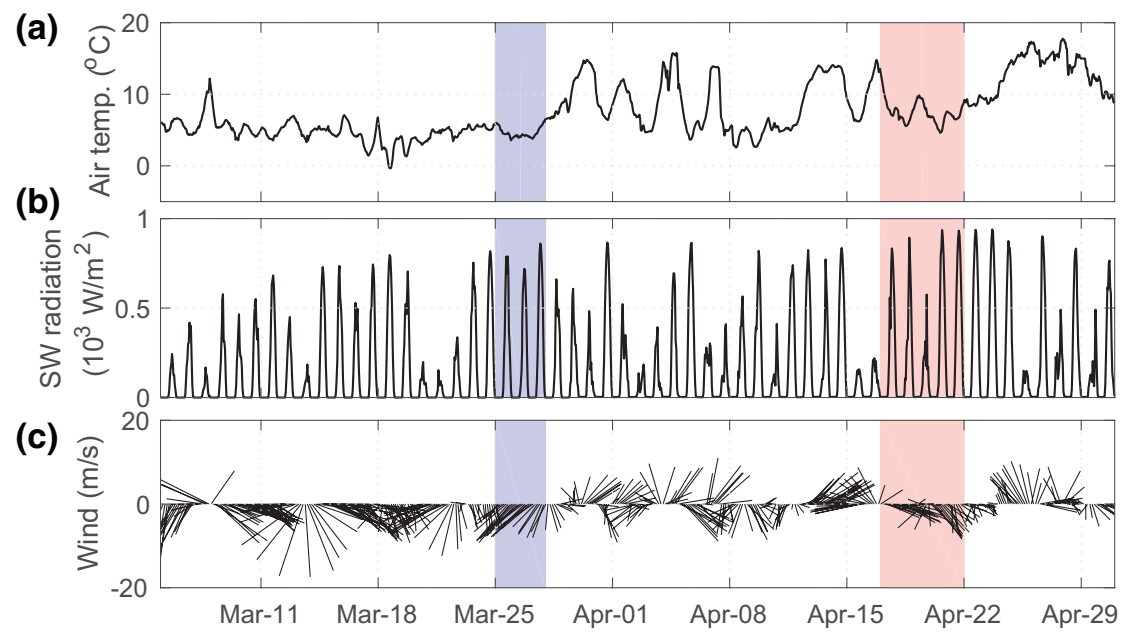

Figure 10. Measured hourly atmospheric temperature (a), shortwave radiation (b) and wind speed and direction (c) at the Pioneer Array mooring site (39.94N, 70.88W). The purple and red shaded regions highlight the periods of northwesterly/northeasterly winds discussed in the text. 
Table 2

Primary Productivity Estimated Using a Bio-optical Model at Stations Where Phaeocystis was Observed

\begin{tabular}{|c|c|c|c|c|c|c|c|}
\hline $\begin{array}{l}\text { Cast } \\
\text { number- } \\
\text { Location }\end{array}$ & Date & $\begin{array}{c}\text { Modeled } \\
\text { primary } \\
\text { productivity } \\
\left(\mathrm{g} \mathrm{C} \mathrm{m}^{-2} \mathrm{~d}^{-1}\right)\end{array}$ & $\begin{array}{l}\text { Euphotic } \\
\text { zone } \\
\text { depths } \\
\text { (m) }\end{array}$ & $\begin{array}{l}\text { Net community } \\
\text { production } \\
\left(\mathrm{mmol} \mathrm{O}_{2}\right. \\
\left.\mathrm{m}^{-2} \mathrm{~d}^{-1}\right)\end{array}$ & $\begin{array}{l}\text { Net } \\
\text { community } \\
\text { production }(g \\
\left.\mathrm{C} \mathrm{m}^{-2} \mathrm{~d}^{-1}\right)\end{array}$ & $\begin{array}{c}\text { Gross oxygen } \\
\text { production } \\
\left(\mathrm{mmol} \mathrm{O}_{2}\right. \\
\left.\mathrm{m}^{-2} \mathrm{~d}^{-1}\right)\end{array}$ & $\begin{array}{l}\mathrm{NCP} / \\
\mathrm{GOP}\end{array}$ \\
\hline 97-A2 & April 23, 2018 & 0.71 & 26 & 146 & 1.25 & 275 & 0.53 \\
\hline $129-\mathrm{A} 2$ & April 26, 2018 & 0.27 & 23 & 182 & 1.56 & 378 & 0.48 \\
\hline $163-\mathrm{A} 2$ & April 28, 2018 & 0.28 & 38 & 146 & 1.25 & 308 & 0.47 \\
\hline 96-A3 & April 23, 2018 & 0.76 & 21 & 269 & 2.30 & 397 & 0.68 \\
\hline $128-\mathrm{A} 3$ & April 26, 2018 & 0.24 & 30 & 142 & 1.22 & 274 & 0.52 \\
\hline $159-\mathrm{A} 3$ & April 28, 2018 & 0.21 & 30 & 130 & 1.11 & 256 & 0.51 \\
\hline 95-A4 & April 23, 2018 & 0.73 & 27 & 229 & 1.96 & 358 & 0.64 \\
\hline $126-\mathrm{A} 4$ & April 26, 2018 & 0.23 & 36 & 157 & 1.34 & 301 & 0.52 \\
\hline $158-\mathrm{A} 4$ & April 28, 2018 & 0.21 & 28 & 118 & 1.01 & 220 & 0.54 \\
\hline $56-\mathrm{A} 5$ & April 21, 2018 & 0.85 & 31 & 56.2 & 0.48 & 161 & 0.35 \\
\hline 94-A5 & April 23, 2018 & 0.58 & 42 & 51.6 & 0.44 & 145 & 0.35 \\
\hline $125-\mathrm{A} 5$ & April 26, 2018 & 0.26 & 32 & 104 & 0.89 & 261 & 0.40 \\
\hline $157-A 5$ & April 28, 2018 & 0.23 & 27 & 32.1 & 0.28 & 47 & 0.68 \\
\hline
\end{tabular}

Notes. Also included are the euphotic depths determined from Morel (1998), the net community production (NCP) estimates from $\mathrm{Ar} / \mathrm{O}_{2}$ measurements, gross oxygen production (GOP) rates from triple oxygen isotopes, and the ratio of $\mathrm{NCP} / \mathrm{GOP}$. Net community production in carbon units converted using a carbon:oxygen ratio of 1.4.

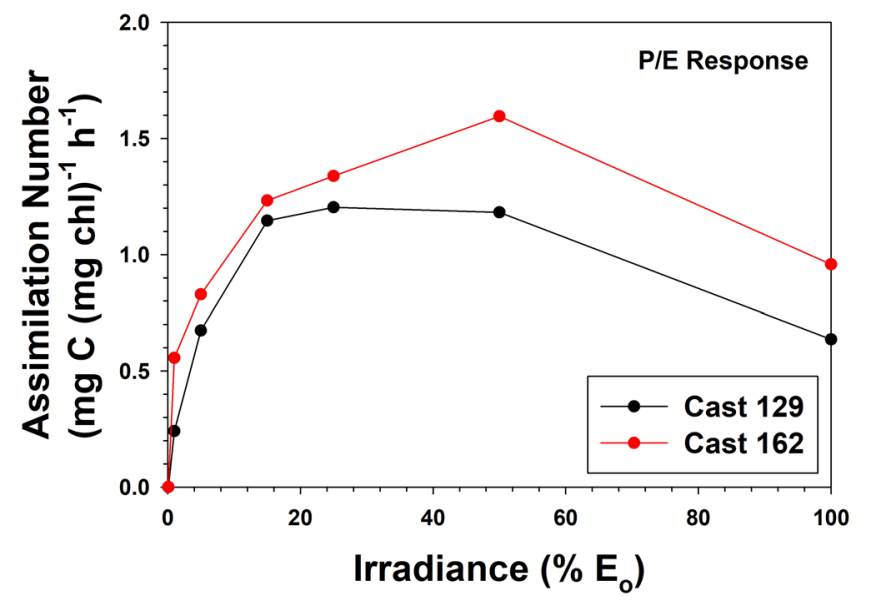

Figure 11. Photosynthesis-irradiance response of Phaeocystis sampled at two locations. Water was collected from 26 and $28 \mathrm{~m}$ at Casts 129 and 162, respectively. The irradiances of the sample depths were $5 \%$ and $1 \%$ of the surface, respectively. water on the shallow shoal. In winter, water on Nantucket Shoals is subject to strong heat loss to the atmosphere, resulting in very low temperatures. The strong tidal currents generate a tidal mixing front at ca. $50 \mathrm{~m}$ that separates the well-mixed water on the shoal from the stratified water offshore (Limeburner \& Beardsley, 1982; Loder \& Greenberg, 1986). This front generally suppresses the cross-isobath water exchange and serves to maintain water and its properties on the shoal, and thus helps explain the persistence of the bloom through time.

The tidal mixing front is not impermeable, however, and, under the influences of winds or frontal instability, well-mixed waters on the shallow shoal can be transported across the 50-m isobath into the deeper continental shelf and beyond. The front is subject to baroclinic instability (e.g., Brink, 2012), which can develop into large-amplitude meanders and eddies that transport water across the front. Wind-induced Ekman transport could also carry water from the shallow shoal across the front into the deeper mid-shelf region. Satellite images show high-chlorophyll Nantucket Shoals water had moved southwestward across the 50-m isobath in the form of filaments on the surface on March 31 and April 21 (Figures 8c and 8d). This is likely a combined effect of the frontal instability and Ekman transport driven by the northeasterly and northwesterly winds over the periods of March 25-28 and April 17-22, respectively (Figure 10).

The shallow depth of Nantucket Shoals ensures that much of the water column is within the euphotic zone. Meanwhile, enhanced vertical mixing on the shoal tends to sustain nutrient concentrations in the water column by mixing the subsurface high-nutrient source water with surface, low-nutrient source waters from the Gulf of Maine. Mixing on the shoal also presumably increases flux of nutrients from the benthos into the euphotic zone and allows some portion of the phytoplankton assemblage to exist in a high-light environment for some fraction of the day. These 

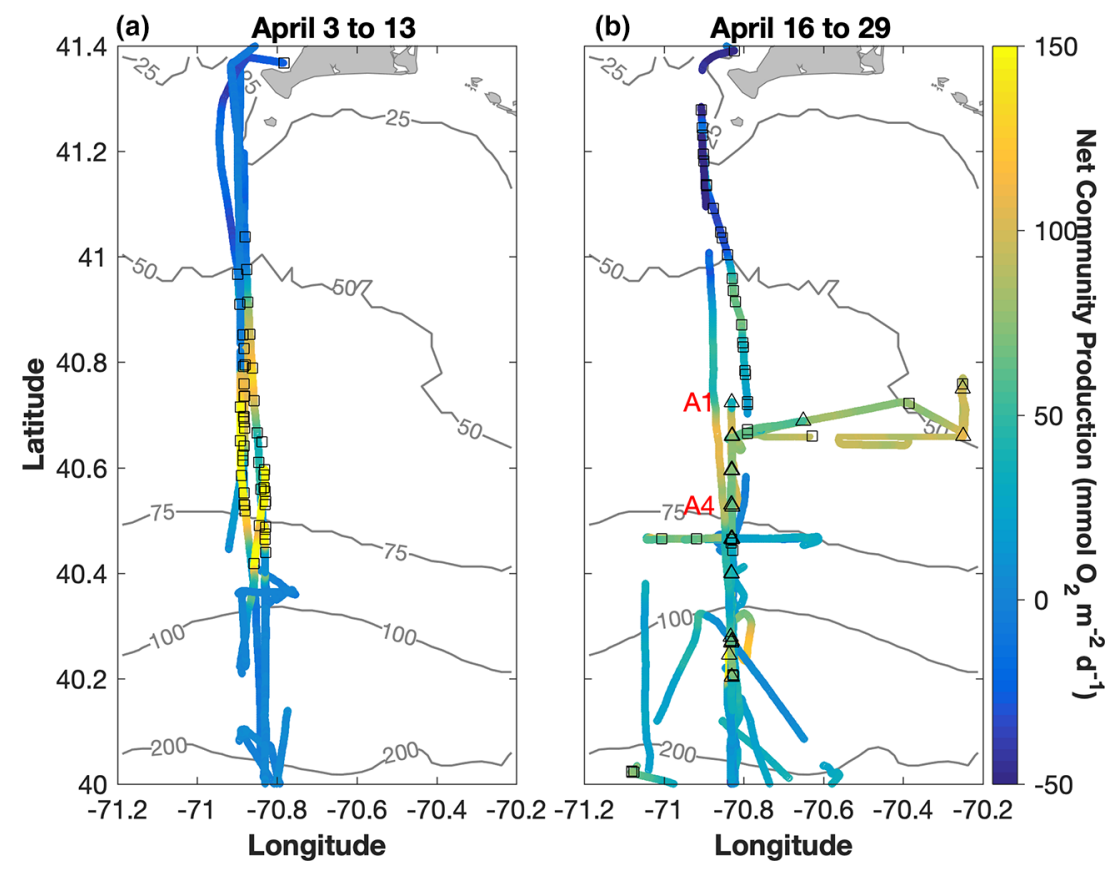

Figure 12. Spatial distribution of mixed layer net community production as determined from underway $\mathrm{O}_{2} / \mathrm{Ar}$ measurements on (a) AR28B (April 2-13) and (b) AR29 (April 16-29). Open squares represent locations where the IFCB showed a biovolume due to Phaeocystis colonies of greater than $10 \mathrm{~mL}^{-1}$, and open triangles represent locations where DAVPR showed abundance of colonies of Phaeocystis greater than 10 colonies $\mathrm{mL}^{-1}$. DAVPR data were not available during AR28B. Note that the IFCB and DAVPR samples are less frequently collected than the NCP data. DAVPR: Digital Autonomous Video Plankton Recorder; IFCB: Imaging Flow Cytobot; NCP: net community production.

factors, together with the capability of Phaeocystis to photosynthesize at low irradiances, enhance phytoplankton growth over Nantucket Shoals.

Initially there was a relatively strong covariance of temperature and chlorophyll (Figure S1), but this relationship weakened and disappeared through time. Other studies have concluded that $P$. pouchetii was stimulated by cold, high precipitation winters in New England coastal waters (Borkman et al., 2016; Hunt et al., 2010; Jiang et al., 2014). Phaeocystis in other systems is clearly stimulated by the addition of nutrients (e.g., Lancelot et al., 1998), although we have no data suggesting that unusual winter inputs of nutrients occurred in the Gulf of Maine. We suggest that the combined low temperatures and elevated winter (non-limiting) nutrient concentrations that result from winter mixing and advection stimulated the growth of Phaeocystis close to the coast, and the bloom (or an inoculum of Phaeocystis cells) was ultimately transported offshore to the Nantucket Shoals region, where it continued to grow and accumulate in that high nutrient environment.

Our observations can be explained in a simple conceptual model (Figure 13). The high Phaeocystis water was initially trapped on Nantucket Shoals by the tidal mixing front until frontal instability or wind-induced cross-isobath flow occurred. The cross-isobath flow carried the Nantucket Shoals water with high concentrations of nutrients and Phaeocystis cells offshore into the surface mixed layer on the stratified mid-shelf. The sufficient irradiance and nutrients in the surface mixed layer allowed the Phaeocystis bloom to persist at mid-shelf until nutrients in the surface layer were reduced. Ultimately, the assemblage was limited by available nitrate (Figure 4) and sank to depth, where intensive mixing suspends Phaeocystis cells in the bottom boundary layer. In the shallow part of the midshelf where the top of the bottom boundary layer is above the $1 \%$ isolume and thus within the euphotic zone, the Phaeocystis cells were exposed to enough light from above and ample nutrients, and the bloom continued its growth, albeit at lower rates than at the surface.

The bloom covered a substantial region of the shelf $\left(\mathrm{ca} .8,000 \mathrm{~km}^{2}\right.$ ) with elevated chlorophyll levels (maximum concentrations $>16 \mu \mathrm{g} \mathrm{L}{ }^{-1}$ ). While the bloom appeared to be mostly constrained in space by physical 


\section{(a) Start of the bloom on Nantucket Shoal}

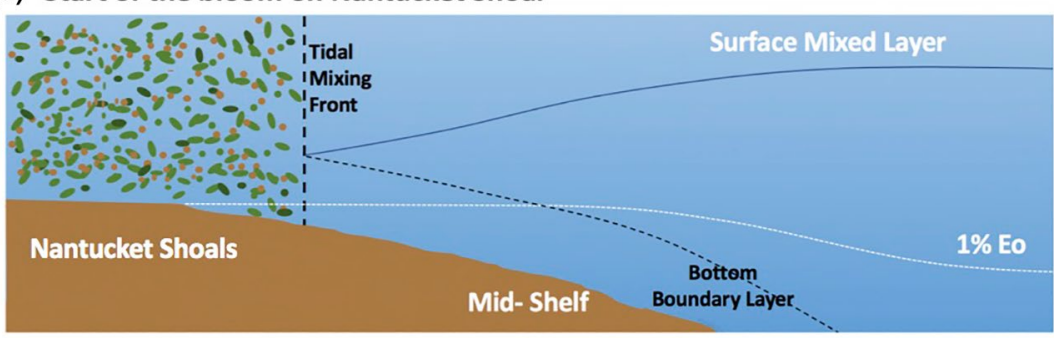

(b) Offshore transport on the surface

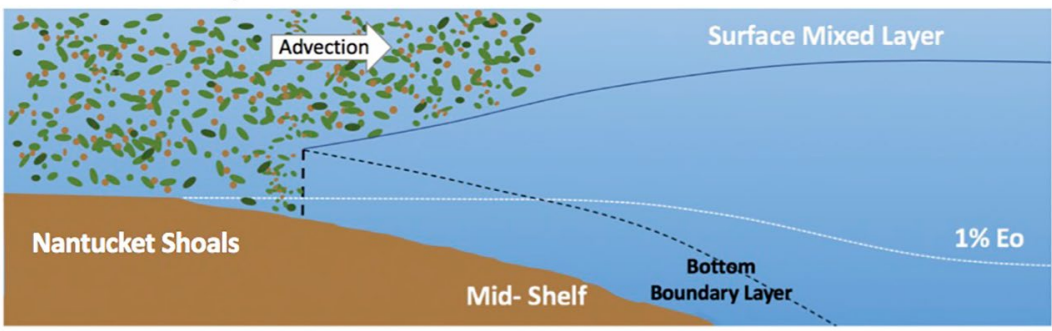

(c) Sinking after the surface nutrient depletion

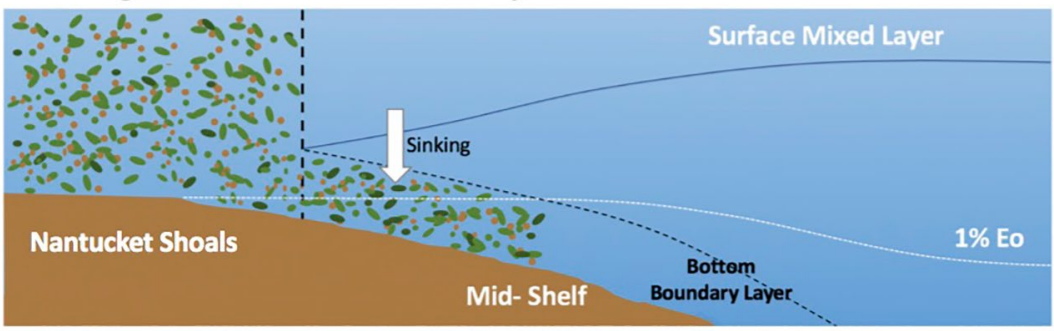

Figure 13. Schematic describing the proposed generation and evolution of the bloom on the New England Shelf (a-c). The depicted locations of the tidal mixing front, the depth of the mixed layer, and the depth of the $1 \%$ isolume (Eo; euphotic zone) were informed by data collected during the cruises.

features such as the tidal mixing front, intermittent exchanges with waters outside of its core (e.g., April 23; Figures 8d and 8e) extended the bloom's spatial extent. After the Nantucket Shoal water filaments with high concentrations of Phaeocystis extended onto the midshelf, the vertical distribution of chlorophyll concentration varied in time. At Stations A2, A3, and A4 chlorophyll exhibited a distinct subsurface maximum; furthermore, this maximum descended to depth over seven days at those stations. This reflects the sinking of Phaeocystis colonies after the nutrient depletion in the surface mixed layer. Integrated chlorophyll concentrations decreased by ca. 50\%, 40\%, and 25\% from the maximum, respectively, at the three stations. Conversely, Station A5 exhibited a surface maximum initially, but this maximum also descended in the water column through time. Crude estimates of the vertical flux of material can be made from the movement of vertical chlorophyll maxima through time (Figure 3). These indicate that the sinking rates of the material were similar at all locations (from 10.1 to $14.2 \mathrm{~m} \mathrm{~d}^{-1}$ ); furthermore, such rates are consistent with passive sinking rates of nutrient-limited phytoplankton measured both in situ and in culture (e.g., Bienfang \& Szyper, 1982; Gemmell et al., 2016). We suggest that the vertical flux of material resulted from the passive sinking of Phaeocystis colonies that had become nitrogen-limited.

Estimates of Phaeocystis maximum rate of photosynthesis and light-limited rates of photosynthesis (Figure 11) are similar to those found in P. antarctica in the Ross Sea (Smith \& Donaldson, 2015), suggesting that there is a similarity between the two species despite the profoundly different environmental conditions each grows in. Similarly, the carbon:nitrogen ratio of the assemblage was greater than the Redfield ratio (Table S1), and similar to that found in P. antarctica dominated waters (Arrigo et al., 1999). More detailed information on the photosynthesis of Phaeocystis from New England waters is needed to fully understand its growth and influence on water column biogeochemistry. 
While estimates of primary productivity from the bio-optical model are modest (Table 2; average of all locations and stations was $0.36 \pm 0.19 \mathrm{~g} \mathrm{C} \mathrm{m}^{-2} \mathrm{~d}^{-1}$ ), estimates based on oxygen:argon ratios were greater and averaged $0.76 \pm 0.39 \mathrm{~g} \mathrm{C} \mathrm{m}^{-2} \mathrm{~d}^{-1}$. This is not surprising, as the two measure productivity over fundamentally different time scales. NCP estimates generally integrate over multiple days, since gas exchange is relatively slow, while the modeled productivity uses the observed vertical chlorophyll distribution and the 24-h irradiance observed after the station had been sampled. Thus, NCP estimates are likely reflecting productivity when the bloom may still have been at the surface.

The NCP and NPP estimates may disagree for other reasons than time-scales. The bio-optical model does not account for the known ability of Phaeocystis to grow at low irradiances (e.g., Smith \& Donaldson, 2015), whereas the NCP and GOP estimates take all growth within the mixed layer into account. The ability of Phaeocystis populations to grow at low irradiances allows it to grow and persist over long time periods on the New England shelf. Using approximate Phaeocystis contributions to chlorophyll, we estimated that the haptophyte during our study was responsible on average for $22 \%$ of the water column productivity

Although more detailed information on the photosynthesis of Phaeocystis from New England waters is needed to fully understand its growth and influence on water column biogeochemistry, the NCP rates measured during this bloom were extreme (e.g., 350-fold larger) compared to rates measured at the same stations one year later when Phaeocystis was not present, indicating that Phaeocystis greatly impacted mixed layer productivity in the region. Furthermore, satellite estimates of productivity in March and April were substantially greater in 2018 relative to 2017 (more than double in April), again indicating the importance of Phaeocystis carbon fixation to the region. Additionally, the ratio of NCP/GOP is nearly double at locations where Phaeocystis was present (0.5-0.68; Table 2) compared to stations without Phaeocystis from other locations on this cruise (average NCP/GOP $=0.27$ ) or to the stations at the same locations in 2019 when there was little to no Phaeocystis (average NCP/GOP $=0.28$; Stanley, unpubl.). The NCP/GOP ratio, similar to the $f$-ratio (Eppley \& Peterson, 1979), is a measure of export or carbon cycling efficiency (Haskell et al., 2017; Juranek \& Quay, 2013). Previous studies have observed the NCP/GOP ratio to be much higher in bloom conditions 0.5 to 0.8 (Goldman et al., 2015) compared to in non-bloom conditions (Juranek \& Quay, 2013). The large ratio observed here, combined with the high NCP rates, suggests that the Phaeocystis bloom is exporting a significant amount of carbon from surface waters to depth. The ratio decreases slightly with time at each station (other than at station A5 where the bloom is later) suggesting that over time, the heterotrophic community is increasingly able to respire the organic matter produced by the Phaeocystis.

To assess the importance of Phaeocystis to the overall productivity of the region, we also compared GOP rates with a year without Phaeocystis. For example, GOP at Stations A2 through A5 was 180\% higher than GOP at those same stations in Spring 2019, a year without a Phaeocystis bloom (Stanley, unpubl.). Interestingly, GOP rates did not decrease with time as NCP did (Table 2). It is possible that community respiration increased in response to the bloom, and therefore decreasing NCP through time while GOP remained elevated-a conclusion is supported by the NCP/GOP ratio. Although GOP and NCP are both elevated within the Phaeocystis bloom compared to the non-bloom year, NCP is higher by a larger percentage than GOP, suggesting that not only is the bloom very productive, but at least initially heterotrophic respiration was low, leading to large export.

As observations during winter and early spring are limited, it is unclear how frequent Phaeocystis blooms occur over broad areas of the continental shelf, and what controls interannual variability. The most extensive record of continuous observations is from the Martha's Vineyard Coastal Observatory, which has recorded phytoplankton composition continuously since 2006. An analysis of those data suggests that Phaeocystis colonies occur regularly along the coast, with sporadic blooms of the magnitude we observed in 2018 (Figure 9). These observations, assuming that similar oceanographic conditions allow Phaeocystis to be transported from close to the coast offshore to the Nantucket Shoals area, suggest that haptophyte blooms may be regular (in approximately half of the years) occurrences on the continental shelf as well. The abundances measured at MVCO in 2018 are also similar to those found during our DAVPR transects.

We recognize that our DAVPR and IFCB measurements do not include Phaeocystis solitary cells. While the IFCB recognizes solitary cells, it is extremely difficult to adequately distinguish these from other picoplankton, and inclusion of solitary cells is beyond the scope of this analysis. Similarly, the DAVPR cannot 
resolve such small cells. In other Phaeocystis blooms the majority of cells occurred in colonies until nutrient depletion, at which time cells apparently were released from the colonial envelope into the water column (Smith et al., 2003). If a similar biological response occurred in our system, we would expect that our estimates of Phaeocystis biomass might be more severely underestimated after the assemblage sank to depth. However, productivity from the small cells would be included in the rate measurements. Net community production was high at some locations where Phaeocystis concentrations were low, but this likely resulted from the temporal differences between oxygen exchange with the atmosphere and sinking of phytoplankton to depth - that is, to say the NCP signal was "left behind" when the bloom sank out of the surface layer.

\section{Conclusions}

Blooms of the haptophyte Phaeocystis occur globally, are known to disrupt ecosystem services significantly, and appear to have fundamentally different impacts on elemental cycles than do diatoms and cyanobacteria. Some studies have suggested that the appearance of Phaeocystis may increase in the coming century in some regions (e.g., Kaufman et al., 2017), but it is unknown if this increase will occur throughout the ocean. We suggest that in New England waters Phaeocystis regularly blooms to significant levels, and is nearly always present at some level during the winter-spring transition. Whether blooms of the magnitude that we studied will become more frequent in the future is of concern, and we suggest that further attention be given to these potentially harmful algal blooms in such an environmentally important region.

\section{Data Availability Statement}

All data used in this analysis can be obtained from the BCO-DMO data repository (https://www.bco-dmo. org/project/748894).

\section{Acknowledgments}

This project was supported by the US National Science Foundation (Grants 1657855,1657803 , and 1657489). NESLTER contributions were supported by grants to HMS from NSF (Grant 1655686) and the Simons Foundation (Grant 561126). VPR operations were supported by the Dalio Explore Fund. We thank Captain Kent Sheasley and the crew of the R/V Neil Armstrong, as well all our SPIROPA colleagues, for assistance at sea. Ms. Bethany Fowler compiled the molecular data to confirm the species identification, and Ms. Olga Kosnyrev greatly assisted in data analysis and quality control. This is VIMS contribution number 3977 .

\section{References}

Arrigo, K. R., Robinson, D., Worthen, D., Dunbar, R., DiTullio, G. R., van Woert, M., \& Lizotte, M. (1999). Phytoplankton community structure and drawdown of nutrients and $\mathrm{CO}_{2}$ in the Southern Ocean. Science, 283, 365-367.

Barkan, E., \& Luz, B. (2011). The relationships among the three stable isotopes of oxygen in air, seawater and marine photosynthesis. Rapid Communications in Mass Spectrometry, 25, 2367-2369. https://doi:10.1002/rcm.5125

Beardsley, R. C., Chapman, D. C., Brink, K. H., Ramp, S. R., \& Schliztz, R. (1985). The Nantucket Shoals Flux Experiment (NSFE79). Part I: A basic description of the current and temperature variability. Journal of Physical Oceanography, 15, 713-748.

Behrenfeld, M. J., \& Falkowski, P. G. (1997a). Photosynthetic rates derived from satellite-based chlorophyll concentration. Limnology \& Oceanography, 42, 1-20.

Behrenfeld, M. J., \& Falkowski, P. G. (1997b). A consumer's guide to phytoplankton primary productivity models. Limnology \& Oceanography, 42, 1479-1491.

Bienfang, P. K., \& Szyper, J. P. (1982). Effets of temperature and salinity on sinking rates on the centric diatom Ditylum brightwellii. Biological Oeanography, 1, 211-223.

Borkman, D. G., Libby, S., Mickelson, M. J., Turner, J. T., \& Jiang, M. (2016). Variability of winter-spring bloom Phaeocystis pouchetii abundance in Massachusetts Bay. Estuaries and Coasts, 39, 1084-1099. https://doi:10.1007/s12237-016-0065-5

Brink, K. H. (2012). Baroclinic instability of an idealized tidal mixing front. Journal of Marine Research, 70, 661-688.

Cassar, N., Barnett, B. A., Bender, M. L., Kaiser, J., Hamme, R. C., \& Tilbrook, B. (2009). Continuous high-frequency dissolved $\mathrm{O}_{2} /$ Ar meas- $^{-}$ urements by equilibrator inlet mass spectrometry. Analytical Chemistry, 81, 1855-1864.

Chapman, D. C., Barth, J. A., Beardsley, R. C., \& Fairbanks, R. G. (1986). On the continuity of mean flow between the Scotian Shelf and the Middle Atlantic Bight. Journal of Physical Oceanography, 16, 758-772. https://doi:10.1175/1520-0485(1986)016<0758 :OTCOMF $>2.0 . \mathrm{CO} ; 2$

Charlson, R. J., Lovelock, J. E., Andreae, M. O., \& Warren, S. G. (1987). Oceanic phytoplankton, atmospheric sulphur, cloud albedo and climate. Nature, 326, 655-661.

Davis, C. S., Thwaites, F. T., Gallager, S. M., \& Hu, Q. (2005). A three-axis fast-tow digital Video Plankton Recorder for rapid surveys of plankton taxa and hydrography. Limnology and Oceanography Methods, 3, 59-74. https://doi.org/10.4319/lom2005.3.59

Emerson, S., Quay, P., Stump, C., Wilbur, D., \& Knox, M. (1991). $\mathrm{O}_{2}$, Ar, $\mathrm{N}_{2}$, and ${ }^{222} \mathrm{Rn}$ in surface waters of the subarctic ocean: Net biological $\mathrm{O}_{2}$ production. Gobal Biogeochemical Cycles, 5, 49-69. https://doi.org/10/1029/90GB02656

Eppley, R. W., \& Peterson, B. J. (1979). Particulate organic matter flux and planktonic new production in the deep ocean. Nature, 282, 677-680.

Falkowski, P. G., Flagg, C. G., Rowe, G. T., Smith, S. L., Whitledge, T. E., \& Wirick, C. D. (1988). The fate of a spring bloom: Export or oxidation? Continental Shelf Research, 8, 457-484.

Garcia, H. E., \& Gordon, L. I. (1992). Oxygen solubility in water: better fitting equations. Limnology \& Oceanography, 37, $1307-1312$.

Gardner, W. D., Richardson, M. J., \& Smith, W. O., Jr. (2000). Seasonal patterns of water column particulate organic carbon and fluxes in the Ross Sea, Antarctica. Deep-Sea Research II, 47, 3423-3449. 
Gawarkiewicz, G. G., \& Plueddemann, A. J. (2018). Scientific rationale and conceptual design in a process-oriented shelfbreak observatory: the OOI Pioneer Array. Journal of Operational Oceanography, 13, 19-36. https://doi10.1080/1755876X

Gemmell, B. J., Oh, G., Buskey, E. J., \& Villareal, T. A. (2016). Dynamic sinking behaviour in marine phytoplankton: Rapid changes in buoyancy may aid in nutrient uptake. Proceedings of the Royal Society B, 283, 20161126. https://doi.org/10.1098/rspb.2016.1126

Goldman, J. A. L., Kranz, S. A., Young, J. N., Tortell, P. D., Stanley, R. H. R., Bender, M. L., \& Morel, F. M. M. (2015). Gross and net production during the spring bloom along the Western Antarctic Peninsula. New Phytologist, 205, 182-191. https://doi:10.1111/nph.13125

Hamme, R. C., \& Emerson, S. (2004). The solubility of neon, nitrogen and argon in distilled water and seawater. Deep-Sea Research I, 51, $1517-1528$.

Hamm, C. E., Simson, D. A., Merkel, R., \& Smetacek, V. (1999). Colonies of Phaeocystis globosa are protected by a thin but tough skin. Marine Ecology Progress Series, 187, 101-111.

Haskell, W. Z., Prokopenko, M. G., Hammond, D. E., Stanley, R. H. R., \& Sandwith, Z. O. (2017). Annual cyclicity in export efficiency in the inner Southern California Bight. Global Biogeochemical Cycles, 31, 357-376. https://doi:10.1002/2016gb005561

Hendricks, M. B., Bender, M. L., \& Barnett, B. A. (2004). Net and gross $\mathrm{O}_{2}$ production in the Southern Ocean from measurements of biological $\mathrm{O}_{2}$ supersaturation and its triple isotope composition. Deep-Sea Research I, 51, 1541-1561.

Hu, Q., \& Davis, C. (2006). Accurate automatic quantification of taxa-specific plankton abundance using dual classification with correction. Marine Ecology Progress Series, 306, 51-61. https://doi:10.3354/meps306051

Hunt, C. D., Borkman, D. G., Libby, P. S., Lacouture, R., Turner, J. T., \& Mickelson, M. J. (2010). Phytoplankton patterns in Massachusetts Bay-1992-2007. Estuaries and Coasts, 33, 448-470. https://doi.10.1007/s12237-008-9125-9

JGOFS. (1996). Protocols for the joint global ocean flux study (JGOFS) core measurements (Report 19). Bergen, Norway: IOC SCOR.

Jiang, M., Borkman, D. G., Libby, P. S., Townsend, D. W., \& Zhou, M. (2014). Nutrient input and the competition between Phaeocystis pouchetii and diatoms in Massachusetts Bay spring bloom. Journal of Marine Systems, 134, 29-44. https://doi.org/10.1016/j. jmarsys.2014.02.011

Juranek, L. W., \& Quay, P. D. (2013). Using triple isotopes of dissolved oxygen to evaluate global marine productivity. Annual Review of Marine Science, 5, 503-524.

Kalnay, E., Kanamitsu, M., Kistler, R., Collins, W., Deaven, D., Gandin, L., Iredell, M., et al. (1996). The NCEP/NCAR 40-year reanalysis project. Bulletin of the American Meteorological Society, 77, 437-471.

Kaufman, D. E., Friedrichs, M. A. M., Smith, W. O., Jr., Hofmann, E. E., Dinniman, M. S., \& Hennings, J. C. P. (2017). Climate change impacts on Ross Sea biogeochemistry: Results from 1D modeling experiments. Journal of Geophysical Research: Oceans, 122, $2339-2359$. https://doi:10.1002/2016JC012514

Lancelot, C., Keller, M. D., Rousseau, V., Smith, W. O., Jr., \& Mathot, S. (1998). Autecology of the marine haptophyte Phaeocystis sp. In D. M. Anderson, A. D. Cembella, \& G. M. Hallagraeff (Eds.), Physiological ecology of harmful algal blooms (Vol. 41, pp. 209-224). Berlin, Germany: Springer-Verlag.

Lentz, S. J., Shearman, R. K., Anderson, S., Pluedemann, A. J., \& Edson, J. (2003). Evolution of stratification over the New England shelf during the Coastal Mixing and Optics study, August 1996-June 1997. Journal of Geophysical Research, 108(C1), 3008. https:// doi:10.1029/2001JC001121.

Limeburner, R., \& Beardsley, R. C. (1982). The seasonal hydrography and circulation over Nantucket Shoals. Journal of Marine Research, 40, 371-406.

Loder, J. W., \& Greenberg, D. A. (1986). Predicted positions of tidal fronts in the Gulf of Maine region. Continental Shelf Research, 6, 397-414.

Lozier, M. S., Reed, M. S., \& Gawarkiewicz, G. (2002). Instability of a shelfbreak front. Journal of Physical Oceanography, $32,924-944$.

Luz, B., \& Barkan, E. (2000). Assessment of oceanic productivity with the triple-isotope composition of dissolved oxygen. Science, 288, 2028-2031.

Manning, C., Stanley, R. H. R., \& Lott, D. E., III (2016). Continuous measurements of dissolved Ne, Ar, Kr, and Xe ratios with a field-deployable gas equilibration mass spectrometer. Analytical Chemistry, 88, 3040-3048. https://doi:10.1021/acs.analchem.5b03102

Marra, J., Houghton, R. W., \& Garside, C. (1990). Phytoplankton growth at the shelf-break front in the Middle Atlantic Bight. Journal of Marine Research, 48, 851-868.

Morel, A. (1998). Optical modeling of the upper ocean in relation to its biogenous matter content (Case I Waters). Journal of Geophysical Research, 93, 10749-10768.

Nejstgaard, J. C., Tang, K. W., Steinke, M., Dutz, J., Koski, M., Antajan, E., \& Long, J. (2007). Zooplankton grazing on Phaeocystis: A quantitative review and future challenges. Biogeochemistry, 83, 147-172.

Nicholson, D., Stanley, R. H. R., \& Doney, S. C. (2014). The triple oxygen isotope tracer of primary productivity in a dynamic ocean. Global Biogeochemical Cycles, 28, 538-552. https://doi:10.1002/2013GB004704

Prokopenko, M. G., Pauluis, O. M., Granger, J., \& Yeung, L. Y. (2011). Exact evaluation of gross photosynthetic production from the oxygen triple-isotope composition of $\mathrm{O}_{2}$ : Implications for the net-to-gross primary production ratios. Geophysical Research Letters, 38 , L14603. https://doi.org/10.1029/2011gl047652

Reuer, M. K., Barnett, B. A., Bender, M. L., Falkowski, P. G., \& Hendricks, M. B. (2007). New estimates of Southern Ocean biological production rates from $\mathrm{O}_{2} / \mathrm{Ar}$ ratios and the triple isotope composition of $\mathrm{O}_{2}$. Deep-Sea Research I, 54, 951-974.

Rousseau, V., Vaulot, D., Casotti, R., Cariou, V., Lenz, J., Gunkel, J., \& Baumann, M. (1994). The life cycle of Phaeocystis (Prymnesiophyceae): Evidence and hypotheses. Journal of Marine Systems, 5, 23-39.

Ryan, J., Yoder, J., Barth, J., \& Cornillon, P. (1999b). Chlorophyll enhancement and mixing associated with meanders of the shelfbreak front in the Mid-Atlantic Bight. Journal of Geophysical Research, 104, 23479-23493.

Ryan, J., Yoder, J., Barth, J., \& Cornillon, P. (1999a). Enhanced chlorophyll at the shelfbreak of the Mid-Atlantic Bight and Georges Bank during the spring transition. Limnology \& Oceanography, 44, 1-11.

Smayda, T. J. (1998). Patterns of variability characterizing marine phytoplankton, with examples from Narragansett Bay. ICES Journal of Marine Science, 55, 562-573.

Smith, W. O., Jr., Dennett, M. R., Mathot, S., \& Caron, D. A. (2003). The temporal dynamics of the flagellated and colonial stages of Phaeocystis antarctica in the Ross Sea. Deep-Sea Research II, 50, 605-618.

Smith, W. O., Jr., \& Donaldson, K. (2015). Photosynthesis-irradiance responses in the Ross Sea, Antarctica: a meta-analysis. Biogeosciences, 12, 1-11.

Smith, W. O., Jr., Liu, X., Tang, K. W., Delizo, L. M., Doan, N. H., Nguyen, N. L., \& Wang, X. (2014). Giantism and its role in the harmful algal bloom species Phaeocystis globosa. Deep-Sea Research II, 60, 95-106. https://doi.org/10.1016/j.dsr2.2012.12.005 
Smith, W. O., Jr., Marra, J., Hiscock, M. R., \& Barber, R. T. (2000). The seasonal cycle of phytoplankton biomass and primary productivity in the Ross Sea, Antarctica. Deep-Sea Research II, 47, 3119-3140.

Smith, W. O., Jr., McGillicuddy, D. J., Jr., Olson, E. B., Kosnyrev, V., Peacock, E. E., \& Sosik, H. M. (2017). Mesoscale variability in intact and ghost colonies of Phaeocystis antarctica in the Ross Sea: Distribution and abundance. Journal of Marine Systems, 166, 97-107.

Sosik, H. M., Futrelle, J., Brownlee, E. F., Peacock, E., Crockford, T., \& Olson, R. J. (2016). hsosik/ifcb-analysis: IFCB-Analysis software system, initial formal release at $v 2$ feature stage (Data set): Zenodo.

Sosik, H. M., \& Olson, R. J. (2007). Automated taxonomic classification of phytoplankton sampled with imaging-in-flow cytometry. Limnology and Oceanography: Methods, 5, 204-216.

Stanley, R. M., Sandwith, Z., \& Williams, W. J. (2015). Rates of summertime biological productivity in the Beaufort Gyre: A comparison between the low and record-low ice conditions of August 2011 and 2012. Journal of Marine Systems, 147, 29-44.

Stefels, J., Dijkhuizen, L., \& Gieskes, W. W. C. (1995). DMSP-lyase activity in a spring phytoplankton bloom off the Dutch coast, related to Phaeocystis sp. abundance. Marine Ecology Progress Series, 123, 235-243.

Teeter, L., Hamme, D., Ianson, R. C., \& Lianucci, L. (2018). Accurate estimation of net community production from $\mathrm{O}_{2} / \mathrm{Ar}_{\mathrm{measurements}}$ Global Biogeochemical Cycles, 32, 1163-1181. https://doi:10.1029/2017GB005874

Verity, P. G., Villareal, T. A., \& Smayda, T. J. (1988a). Ecological investigations of blooms of colonial Phaeocystis pouchetii-I. Abundance, biochemical composition, and metabolic rates. Journal of Plankton Research, 10, 219-248.

Verity, P. G., Villareal, T. A., \& Smayda, T. J. (1998). Ecological investigations of blooms of colonial Phaeocystis pouchetii-II. The role of life-cycle phenomena in bloom termination. Journal of Plankton Research, 10, 749-766.

Wang, S., Elliott, S., Maltrud, M., \& Cameron-Smith, P. (2016). Influence of explicit Phaeocystis parameterizations on the global distribution of marine dimethyl sulfide. Journal of Geophysical Research: Biogeosciences, 120, 2158-2177. https://doi.org/10.1002/2015JG003017

Wilkin, J. L. (2006). The summertime heat budget \& circulation of southeast New England shelf waters. Journal of Physical Oceanography, 36, 1997-2011. https://doi:10.1175/JPO2968.1

Xu, Y., Chant, R. J., Gong, D., Castelao, R., Glenn, S. M., \& Schofield, O. (2011). Seasonal variability of chlorophyll a in the Mid-Atlantic Bight. Continental Shelf Research, 31, 1640-1650. https://doi:10.1016/j.csr.2011.05.019

Zhang, W. G., \& Gawarkiewicz, G. G. (2015b). Dynamics of the direct intrusion of Gulf Stream Ring Water onto the Mid-Atlantic Bight Shelf. Geophysical Research Letters, 42, 7687-7695. https://doi:10.1002/2015GL065530

Zhang, W. G., \& Gawarkiewicz, G. G. (2015a). Length-scale of the finite-amplitude meanders of shelfbreak fronts. Journal of Physical Oceanography, 45, 2598-2620.https://doi:JPO-D-14-0249.1

Zhang, W. G., McGillicuddy, D. J., \& Gawarkiewicz, G. G. (2013). Is biological productivity enhanced at the New England Shelfbreak Front? Journal of Geophysical Research: Oceans, 118, 517-535. https://doi:10.1002/jgrc.20068

\section{References From the Supporting Information}

Linder, C., Gawarkiewicz, G., \& Pickart, R. (2004). Seasonal characteristics of bottom boundary layer detachment at the shelfbreak front in the Middle Atlantic Bight. Journal of Geophysical Research, 109(C3). https://doi.org/10.1029/2003JC002032

Platt, T., \& Jassby, A. D. (1976). The relationship between photosynthesis and light for natural assemblages of coastal marine phytoplankton. Journal of Phycology, 12, 421-430.

Siegel, D. A., Doney, S. C., \& Yoder, J. A. (2002). The North Atlantic spring phytoplankton bloom and Sverdrup's critical depth hypothesis. Science, 296, 730-733. 